\title{
Sensing Glycans as Biochemical Messages by Tissue Lectins: The Sugar Code at Work in Vascular Biology
}

\author{
Herbert Kaltner $^{1}$ Hans-Joachim Gabius ${ }^{1}$ \\ ${ }^{1}$ Institut für Physiologische Chemie, Tierärztliche Fakultät, \\ Ludwig-Maximilians-Universität München, München, Germany \\ Thromb Haemost 2019;119:517-533.
}

\begin{abstract}
Address for correspondence Hans-Joachim Gabius, PhD, Institut für Physiologische Chemie, Tierärztliche Fakultät, Ludwig-MaximiliansUniversität München, Veterinärstr. 13, D-80539 München, Germany (e-mail: gabius@tiph.vetmed.uni-muenchen.de).
\end{abstract}

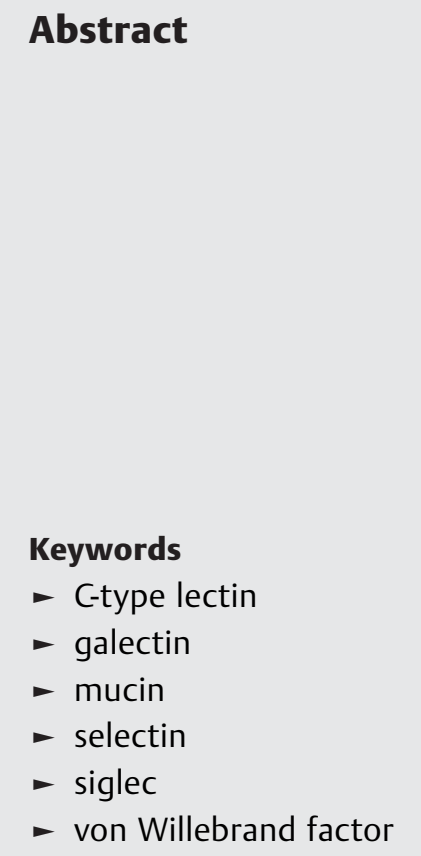

Although a plethora of players has already been revealed to be engaged in the haemostatic system, a fundamental consideration of the molecular nature of information coding can give further explorations of the mechanisms of blood clotting, platelet functionality and vascular trafficking direction. By any measures, looking at ranges of occurrence and of potential for structural versatility, at strategic positioning to influence protein and cell sociology as well as at dynamics of processing and restructuring for phenotypic variability, using sugars as an alphabet of life for generating the glycan part of glycoconjugates is a success story. The handiwork by the complex system for glycan biosynthesis renders biochemical messages of exceptionally high coding capacity available. They are read and translated into cellular effects by receptors termed lectins. The different levels of regulation on both sides, that is, glycan and lectin, establish an intriguingly fine-tuned capacity for functional pairing. The emerging insights into the highly branched routes of glycosylation, into lectin structures up to complete characterization in solution and the shape of lectin networks, first obtained for the three selectins, now extended to considering many other C-type lectins, galectins and siglecs, as well as into intra- and inter-family crosstalk and cooperations are sure to push boundaries in our understanding of the molecular basis of haemostasis.

\section{Introduction}

The cell surface is the platform for a multitude of recognition processes. They can lead to selective cross-linking events within the membrane (lattice formation) and hereby, for example, trigger outside-in signalling. Moreover, bridging between cells or cells and the extracellular matrix can be facilitated. Mechanistically, the complementarity between surface epitopes and their receptors underlies the specificity of these cis/trans-interactions. Allegorically spoken, a molecular message is 'read' and 'translated' into a post-binding effect, that is, biochemically coded information is turned into a process and an outcome. Considering the stringent space limitations on the surface and the large size of the pool of signals relevant to cover all aspects of cell sociology, it immediately becomes apparent that the biochemical information coding is required to reach a high density. To do so, the building blocks (letters of an alphabet of life) of the molecular messages should be able to form many structural isomers (words) with as few constituents as possible. How is this chemically feasible?

In principle, ways of making connections between units to build a biopolymer chain are known from the 5', 3'-phosphodiester of nucleic acids or peptide bonds of proteins. In each case, the same chemistry is applied in a uniform Legolike manner so that exclusively the sequence matters for information coding. With focus on this aspect, that means that going beyond the spatial order of units linked to each other in exactly the same way will open opportunities to received

October 1, 2018

accepted after revision

November 15, 2018 (c) 2019 Georg Thieme Verlag KG Stuttgart · New York
DOI https://doi.org/ $10.1055 / \mathrm{s}-0038-1676968$. ISSN 0340-6245. 
increase the informational contents of oligomers. Explicitly, if variations in the positions and topological properties of connecting points (and branching) become regular features of oligomers, then the extent of structural diversity will be greatly enhanced, and, indeed, one class of biomolecules offers to realize this potential: carbohydrates (for common structures, please see $\mathbf{- F i g . ~ 1 ; ~ f o r ~ o v e r v i e w s ~ o n ~ t h e i r ~ d i v e r - ~}$ sity and properties, please see Gabius ${ }^{1}$ ). Our review introduces readers to the biochemical basis of the concept of the sugar code and respective recognition systems with relevance for vascular biology.

Known to be present abundantly and ubiquitously in nature, as polysaccharides and as conjugates with lipids and proteins, in these cases positioned strategically as 'sugary coating of cells', ${ }^{2}$ glycans have the widespread occurrence profile and surface presentation expected of a basic coding system. ${ }^{3-14}$ Equally important to note, the positioning of the (glycosidic) bond that brings the anomeric centre (marked for each carbohydrate shown in - Fig. 1) of an activated sugar donor together with one of the hydroxyl groups of the acceptor during chain elongation has many more options than just one, what is the case in nucleic acids and proteins. Structurally, variability in linkage position and in anomeric status of the glycosidic bond ( $\alpha$ or $\beta$ ), the possibility for branching and also the introduction of various site-specific substitutions explain why, 'among all biological molecules, carbohydrates, in a short sequence, can potentially display the largest number of ligand structures'. ${ }^{15}$

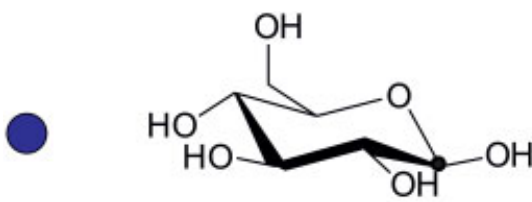

$\beta$-D-glucose (GIC)

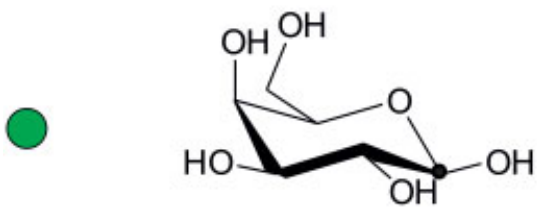

$\beta$-D-galactose (Gal)

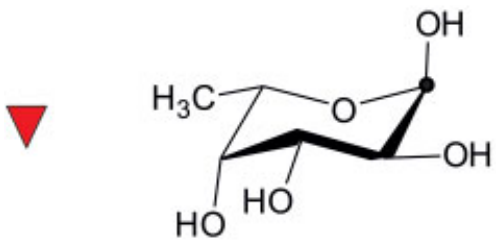

$\alpha$-L-fucose (Fuc)<smiles>CC(=O)N[C@H](C(O)O)[C@H](O)[C@H](O)C[C@@H](O)CO</smiles>

$\mathrm{N}$-acetyl- $\alpha$-neuraminic acid (Neu5Ac)

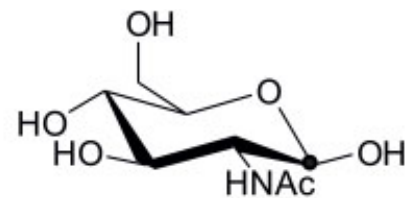

$\beta$-N-acetyl-D-glucosamine (GlcNAc)<smiles>OC[C@@H]1OC[C@@H](O)[C@@H](O)[C@@H](O)O1</smiles>

$\beta$-N-acetyl-D-galactosamine (GalNAc)<smiles>OC1CC2C(O)C(O)C(O)C1C2O</smiles>

$\alpha$-D-mannose (Man)<smiles>O=C(CO)N[C@H](O)[C@H](O)C[C@@H](O)[C@H](O)CO</smiles>

$\mathrm{N}$-glycol(o)yl- $\alpha$-neuraminic acid (Neu5Gc)

Fig. 1 Main letters of the sugar alphabet present in vertebrate glycans. The anomeric centre, the site of conjugation to an acceptor for glycan chain elongation, is marked by a black dot, and the typical colour symbol is given for each sugar. A change in the position of a single OH group (from equatorial to axial) is sufficient to alter the character of the letter, i.e., by epimer formation (Glc to Gal or to Man), as is its exchange by an N-acetyl group (GlcNAc, GalNAc). Reduction to obtain a deoxy sugar (i.e. for the exocyclic methyl group in the C6 position in L-Fuc) or an introduction of an additional hydroxyl group in the side chain to obtain Neu5Gc from Neu5Ac are further means to increase the pool size of this alphabet of life. The type of anomeric position for each compound is given in the monosaccharide's name. 
This assumption will gain impact when this pool size reaches impressive numbers. Calculated for amino acids and for carbohydrates, a set of 20 types of monomers will theoretically build $6.4 \times 10^{7}$ hexapeptides but to as many as $1.44 \times 10^{15}$ hexasaccharides. ${ }^{15}$ As concisely emphasized by Roseman, this exceptional level of structural diversity has its enormous pros but also imparts a practical con for analytical glycoscience: 'glycoconjugates are much more complex, variegated and difficult to study than proteins or nucleic acids', ${ }^{16}$ nonetheless giving ample reason to be 'intrigued as to whether these sugars might be arranged in specific sequences that function as information molecules in biological processes. ${ }^{17}$ Their capacity to store information and to transmit it by inter-molecular recognition is the basis of the sugar code.

Pioneering work to give substance to the concept of the sugar code applied enzymatically editing surface glycans of ${ }^{32}$ P-labelled cells and following their in vivo routing. Using an enzyme fraction from Clostridium perfringens rich in $L-$ fucosidase activity, 'alteration of lymphocytes by glycosidases profoundly affects their fate in the body'. ${ }^{18}$ Instead of their typical recirculation to lymph nodes, increased quantity of radioactivity was found in the liver. ${ }^{18}$ Interestingly, a similar phenomenon of re-programming of routing was discovered when measuring the kinetics of clearance of a ${ }^{64} \mathrm{Cu}$-labelled glycoprotein (i.e. ceruloplasmin) from serum by the liver: enzymatic removal of terminal sialic acids from the glycan chains of ceruloplasmin, what caused presentation of intact galactose (Gal) residues, drastically shortened the period of asialoglycoprotein's serum presence. ${ }^{19}$ Since the status of desialylation can be an indicator of a glycoprotein's lifetime like a timer, a functional correlation between the level of Gal presence at terminal position and hepatic uptake of the processed glycoprotein makes sense physiologically. Obviously, the hepatocytes (somehow) 'read' the message encoded in Gal-terminated glycans, as removal of fucose (Fuc) moieties erases the signal for lymphocyte homing.

In both instances, a distinct glycan signal (on the cell surface or as part of a glycoprotein) appears to serve as molecular equivalent of a postal code (in lymphocyte homing and glycoprotein clearance from circulation). This idea also emerged from studying other systems of cell adhesion such as neuronal or teratoma cells, ${ }^{20}$ setting the stage to move the limelight to glycans. All that can only happen if the enzymatic assembly of glycans is a non-random process so that a large panel of epitopes with their own physiological meaning can be produced, and this independent of a template. The letters of the sugar alphabet are thus expected to be arranged in a highly ordered manner on proteins (and on sphingolipids), as meaningful words in any language are separated from purely random (non-sense) combinations. In this sense, 'the significance of the glycosyl residues (of glycoconjugates) is to impart a discrete recognitional role on the protein.'. ${ }^{21}$ This fundamental conclusion prompts us to first introduce the 'letters', to comment on the chemistry of their conjugation to 'words' next and then describe the enzymatic machinery 'writing' glycan-encoded messages.

\section{The Sugar Code: Glycans as Signals}

The examples of nucleic acids and proteins teach us how an enzymatic process connects letters of the first and second alphabets of life to messages. In general, an activated donor is used for chain elongation, and this at a single site of the acceptor. Taking the place of nucleotide triphosphates and aminoacyl adenylates, known from the other two types of biopolymer synthesis, are glycoside conjugates with nucleotides (uridine diphosphate, guanosine diphosphate or cytidine monophosphate) at the respective sugar's anomeric centre. These activated sugar derivatives are the substrates for the enzymes to let a sugar chain grow, that is, glycosyltransferases. The most frequently used structural units (letters) for glycan biosynthesis in mammals are shown in -Fig. $\mathbf{1}$.

Since hydroxyl groups of acceptor carbohydrates (for hexopyranoses such as glucose [Glc] or Gal shown in - Fig. 1) are chemically rather equivalent, variability in linkage positions will be possible if the enzymatic assembly line is equipped with respective sets of tools. Indeed, this is the case so that glycosidic linkages with $(\alpha$ or $\beta) 1,2$ - or $1,3-$ or $1,4-$ or 1,6 connections can be formed. As a consequence, a disaccharide is not only structurally defined by its sequence but also by these two additional parameters. For example, Gal $1,4 \mathrm{Glc}$, Gal $\beta 1,4 \mathrm{Glc}$ or Gal $\beta 1,6 \mathrm{Glc}$ are different compounds ('words') that all share the Gal-Glc sequence.

In contrast to homopolysaccharides such as chitin or cellulose with their uniform $\beta 1,4$-linkage of $\mathrm{Glc}(\mathrm{NAc})$ residues, glycans of cellular glycoconjugates are the proof that the potential of carbohydrates to build oligomers of enormous diversity is actually exploited. The same substrate, that is, the sugar of its nucleotide derivative, can enter an acceptor glycan at different positions depending on enzyme and acceptor presence. This principle that underlies the origin of glycan complexity is graphically illustrated by an example from the maturation of $\mathrm{N}$-glycans of glycoproteins.

The pentasaccharide core of $\mathrm{N}$-glycans shown in - Fig. $\mathbf{2}$ is the common substrate for processing towards all forms of complex-type N-glycans. Six sites exist for branch initiation by site- and position-specific addition of $\mathrm{N}$-acetylglucosamine (GlcNAc) in $\beta 1$-linkage via distinct $\mathrm{N}$-acetylglucosaminyltransferases (GnTs), as listed in — Fig. 2. Linkages are in $\beta 1,2 / 4 / 6$, and

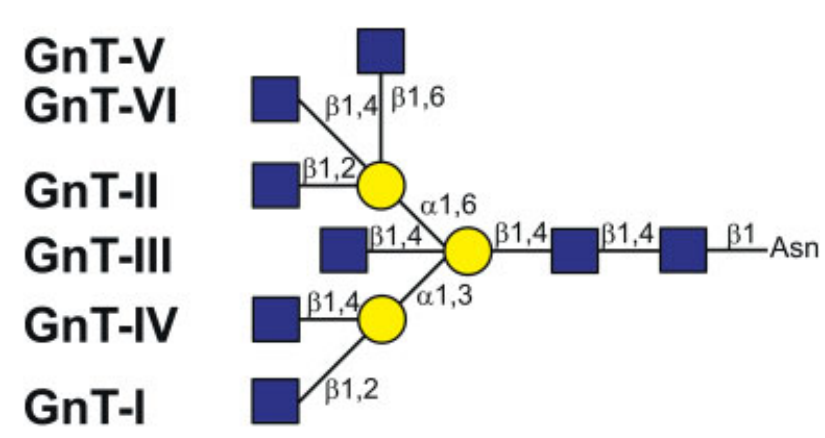

Fig. 2 The six modes of GICNAc incorporation into the $\mathrm{N}$-glycan core pentasaccharide by $\mathrm{N}$-acetylglucosaminyltransferases (GnTs). Their activity in the order of numbers given to each enzyme initiates production of up to penta-antennary complex-type $\mathrm{N}$-glycans. For explanations of symbols for sugars, please see legend to - Fig. 1 . 
each GnT has its specific acceptor, working in the assembly line at a position as indicated by the given numbers. Viewed systematically, large enzyme panels, too, are available for each other type of carbohydrate so that the toolbox of glycosyltransferases is well equipped for making glycan diversity and complexity possible. ${ }^{22-37}$ The connection of impairing certain enzymes of glycan biosynthesis to causing pathological phenotypes of mice deficient in the responsible genes underscores their relevance for cellular physiology ${ }^{38}$ In these studies, important clues may even be missed, because compensatory mechanisms have been tracked down that maintain certain glycome features despite the engineered deficiency. ${ }^{39,40}$ The dynamic nature of availability of substrate, acceptor and enzyme accounts for the broad spectrum of the glycome and its spatiotemporal diversity. ${ }^{41-47}$

Overall, carbohydrates have the chemical features to make the envisioned high-density coding possible, and an enzymatic machinery has been developed to realize this potential. Variations in anomeric position and in linkage points enable the glycome to be composed of a huge number of structures-at the same time posing demanding challenges to structural glycan characterization. Progress in glycan analysis $^{48-50}$ and synthesis ${ }^{51}$ has laid the foundation for aiming at delineating structure-function relationships. As important as the presence of the hydroxyl groups (in axial/ equatorial positions) is for structural variability, it then is for making directional hydrogen bonding possible, and there is more: in contrast to most peptides, glycans are not highly flexible. Within their conformational space, they often access few low-energy 'valleys' (conformers), a boon in the thermodynamic balance sheet when binding to a receptor. ${ }^{52}$ Hereby, the entropic penalty is rather low, favouring binding. In aggregate, the hypothesis for a flow of information from glycans as ligands (counter-receptors) via a recognition process ('reading') by receptors and a translation of the glycan-encoded information into biological effects by this functional pairing is attractive and testable.

Historically, an antibody-to-antigen-like association has been discussed approximately 70 years ago. ${ }^{53,54}$ Worded prophetically, 'rather than trying to force all biological specificity into the immunological compartment, we might have to consider the latter as merely a special case of the more universal biological principle, namely, molecular key-lock configuration as a mechanism of selectivity, ${ }^{54}$ here drawing on Fischer's famous lock-and-key analogy derived from his work with the glycosidases 'Invertin und Emulsin'. ${ }^{55}$ Within this concept, the two key questions that we must answer are as to whether (antibody-like) receptors for glycans exist and, if positive, whether their presence shows the necessary degree of diversification for accomplishing the assumed task of decoding of a large array of glycan-encoded signals.

\section{The Sugar Code: Lectins as Readers| Translators}

A simple and robust assay was crucial to detect lectin activity, that is, haemagglutination. The bridging of erythrocytes by at least bivalent proteins that leads to visible cell aggregation was the experimental read-out for the discovery of (haem) agglutinins, first in rattlesnake venom (1860), and then in plant extracts (1888). Mitchell put one drop of venom on a slide, and a drop of blood from pigeon's wounded wing (was) allowed to fall upon it. They were instantly mixed. Within three minutes the mass had coagulated firmly, ${ }^{56}$ the landmark discovery of receptors bridging cells by ligand binding (an involvement of plasma compounds in the 'coagulation' was rigorously excluded $\sim 40$ years later, ${ }^{57}$ and the active protein biochemically characterized more than 100 years later). ${ }^{58}$

Giving these agglutinins further medical relevance, members of this family of effectors were described that could even equal the ability of serum antibodies in distinguishing the blood group status of human donors (for historical survey, please see Refs. ${ }^{46,47}$ and ${ }^{59-61}$ ). That constituents of plant extracts could thus 'read' surface determinants of erythrocytes as the blood group-specific antibodies do, which Landsteiner described as cause for fatal incompatibilities in blood transfusion, ${ }^{62,63}$ which inspired Boyd to shape a generic name for these activities: 'it would appear to be a matter of semantics as to whether a substance not produced in response to an antigen should be called an antibody even though it is a protein and combines specifically with a certain antigen only. It might be better to have a different word for the substances and the present writer would like to propose the word lectin from Latin lectus, the past principle of legere meaning to pick, choose or select'. ${ }^{64}$

Instead of using a term like antibody-like substance with implicit structural comparison, the emphasis was wisely placed on a feature of ligand binding, 'intending thus to call attention to their specificity without begging the question as to their nature', while certainly being intrigued by the observations that "lectins imitate the behaviour of immune antibodies'. ${ }^{65}$ When asked (in 1973) how he would define a lectin, Boyd replied: 'that although he had invented the word he had no right to dictate what it should mean. He said that once a word goes into general circulation it becomes independent of its originator and eventually becomes whatever people think it ought to mean! He added that he would like to use the word to mean a protein that had a more or less specific action and that there is no reason to think it is an antibody. ${ }^{66}$ Over time, lectin became the most common name for agglutinating activities, although the synonym (phyto)haemagglutinin is still in use, for example, for two bean (Phaseolus vulgaris) lectins (PHA-E/L; their mixture holds a special place in lectinology, because the induction of mitogenesis in human leukocytes by PHA proved elicitor capacity of lectin binding for the first time ${ }^{67}$ ) and for a lectin of the influenza viral surface. Thus, lectins qualify as receptors, and investigating their specificity to cellular targets unveiled glycans as counter-receptors.

That their specificity is directed to glycans can historically be traced to reporting a 'de-agglutination' of erythrocyte aggregates that had formed in the presence of ricin or abrin preparations by using hog gastric mucin, a potent lectin binder. ${ }^{68,69}$ Blocking haemagglutination in the presence of blood group-specific lectins by a sugar, first Fuc inhibiting the activity of the lectin of eel serum to cross-link type $\mathrm{O}(\mathrm{H})$ 
erythrocytes, ${ }^{70}$ proved carbohydrate binding beyond doubt, and this approach was systematically followed in transfusion medicine and in lectinology in general. ${ }^{71}$ Terminologically, carbohydrate binding is the first criterion for a lectin, a feature yet shared by other classes of proteins such as immunoglobulins (Igs), as the mentioned antibodies attest, and glycosyltransferases. Thus, besides carbohydrate-binding antibodies, lectins need to be strictly separated from any enzyme using a carbohydrate as substrate, from sensors/ transporters for free mono- and oligosaccharides and carbohydrate-binding modules of bacterial and fungal glycoside hydrolases. ${ }^{72,73}$

To have the implied broad impact on many aspects of cellular physiology, the range of glycan-lectin recognition must not be narrow. Implicitly, this means that lectins must not be a rare commodity in the proteome. The implied functional pairing is assumed to account for a co-evolution towards diversity. Indeed, matching diversity on the level of glycans, more than a dozen protein folds have developed capacity to interact with glycans (for three examples, please see - Fig. 3; complete illustration of the folds of the families of animal/human lectins is given in Fujimoto et $\mathrm{al}^{74}$ and in the Gallery of Lectins in Solís et al, ${ }^{75}$ along with a detailed listing and description of methods to analyse complex formation of a lectin with its ligand in that paper's table 1).

This is similarly seen on the level of glycogenes. They code for glycosyltransferases, glycosidases, glycan-modifying enzymes such as sulfotransferases (please see below) and enzymes for carbohydrate biosynthesis such as for the two sialic acids shown in the bottom part of $\mathbf{- F i g} . \mathbf{1}$ and for the ensuing generation of the activated carbohydrates as well as for transporters of activated sugars. Diversification of the gene for each ancestral lectin (or glycogene product) has led to families of genes. In the case of lectins, they code for homologous proteins with differences in fine specificity (due to the sequence alterations within the carbohydrate recognition domain [CRD]) and in the architecture in terms of modular display. Intriguingly, a CRD can be embedded into a complex structural context, with often not yet resolved physiolocal relevance.
In fact, the CRD can be part of a multi-modular protein, and individual regions can functionally cooperate, for example, to form aggregates (such as galectin-3; please see below) or to guide a lectin to the extracellular space, where it then mediates ordered cell migration. ${ }^{76}$ When thoroughly examining occurrence of proteins with any of the three folds illustrated in -Fig. 3 as examples, it turned out to be a common theme within phylogenesis that lectin diversity is truly attained commonly on the level of families. This apparent co-evolution with glycans resulting in large lectin numbers strongly argues in favour of the assumed role of lectins as translators for the large panels of glycan-encoded messages. ${ }^{77}$ This intra-family divergence is described in further detail for C-type lectins (please see reviews ${ }^{78-80}$ ), for sialic acid-binding Ig superfamily lectins (siglecs) (please see ${ }^{81,82}$ ) and for ga (lactose-binding)lectins ${ }^{83-88}$. Notably, in all three cases, species differ in qualitative aspects of gene display and also with respect to gene number and organization, for example, for mammalian galectins ${ }^{84,89}$ so that extrapolations from animal models to the clinical situation should always be performed with adequate caution.

Having identified this wide range of carbohydrate-binding motifs and detected a large number of endogenous lectins, the two fundamental questions posed at the end of the previous chapter are convincingly answered with a 'Yes'. The current challenge therefore is to proceed from completing the phase of lectin discovery to entering the era of building a functionally meaningful puzzle from the individual proteins. ${ }^{90}$ First, a lectin must be assigned to its binding partners and pairing is very selective. Next, respective studies are revealing that members of lectin families appear to be expressed in networks. This raises the possibility for functional crosstalk (antagonism or cooperation) in cis/trans-interactions and in sensing non-self-signals. Obviously, the concept of lectins expressed in networks deserves to become a paradigm. The multiplicity of lectin representation is, for example, in certain cell types or tissues, attested by discovering a large group of myeloid C-type lectins ${ }^{91}$ and by revealing overlapping roles of C-type lectins in anti-microbial and anti-fungal immunity. ${ }^{92,93}$

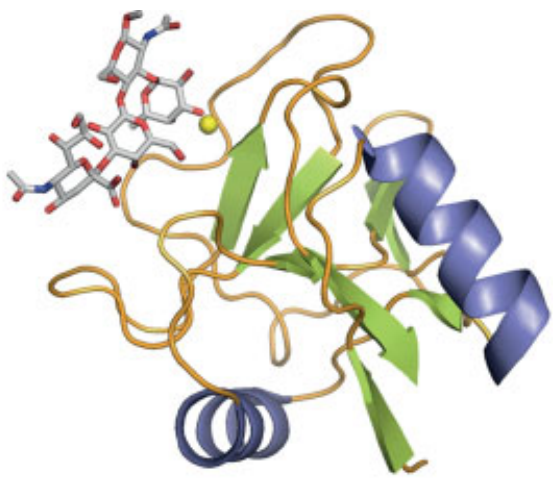

A
B

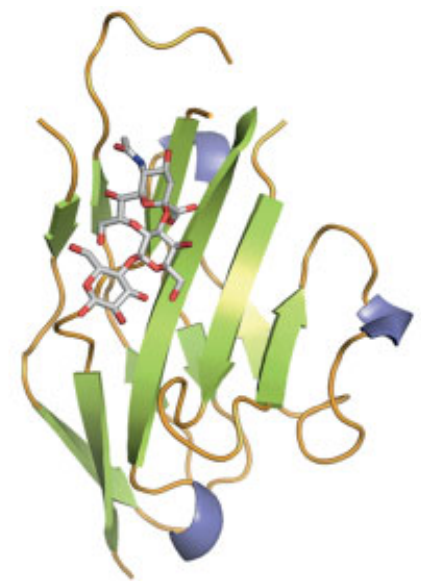

C

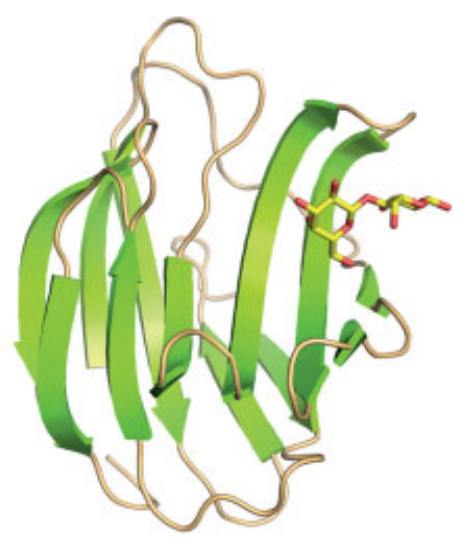

Fig. 3 Illustration of three examples of basic folds of mammalian lectins with bound ligand, that is, C-type lectin E-selectin (A; Protein Data Bank [PDB] code: 1G1T), siglec-1 (sialoadhesin) (B; PDB code: 1QFO) and galectin-1 (C; PDB code: 1GZW). 
First detected by immunohistochemistry with non-cross-reactive antibody preparations, galectins analysed up to the level of full-scale monitoring of the complete set of family members are expressed in distribution profiles with individual features and overlaps. ${ }^{94-98}$ These results, of course, have immediate relevance for the strategy how to analyse lectin activities, that is, in mixtures. Initial comparative study of galectin activities alone and in mixtures has been performed by testing surfacetailored glycodendrimersomes in bridging assays ${ }^{99,100}$ and by using cell-based functional assays. ${ }^{101-103}$ The obtained evidence for functional interplay encourages to study in more detail what will happen when lectins are tested alone and in combinations simulating in vivo conditions, and this by using members of the same family and of different families.

In summary, presence of sophisticated machineries for lipid and protein glycosylation, producing the ligand side, and for glycan recognition, the complementary side, clearly supports the concept of an information transfer by glycan-protein interactions (sugar code) and gives cracking the sugar code direction. ${ }^{104}$ The aim is to define the meaning of a glycan in its cellular context. Following this concept, distinct carbohydrate epitopes of glycan chains of cellular glycoconjugates can be expected to engage in functional pairing with certain tissue (endogenous) lectins. Any structural processing (for example, stepwise chain elongation) should then change the glycan's ligand properties, that is, its biochemical meaning. By looking exemplarily at main products of $\mathrm{N}$ - and mucin-type O-glycan biosynthesis, the hypothesis that a series of functional pairings occurs along the biosynthetic pathways is next put to the test, first for branch ends of complex-type N-glycans. At the same time, the following description of routes of glycan processing itself documents that many branch points exist to let glycan diversity reach an amazing level.

\section{Functional Pairing: N-Glycans}

$\mathrm{N}$-glycosylation is a co-translational process that is started at the signal-peptide-dependent entry of a nascent protein into the endoplasmic reticulum (ER). The $\mathrm{Glc}_{3} \mathrm{Man}_{9} \mathrm{GlcNAc}_{2}$ oligosaccharide is transferred from its dolichol pyrophosphate donor to the $\mathrm{N}$-atom of an asparagine (Asn) moiety within a protein's N-glycosylation (sequon) motif [i.e. Asn-Xaa (no Pro)Ser/Thr-Xaa (no Pro)]. ${ }^{29}$ During the early stage of the pathway of $\mathrm{N}$-glycan processing and maturation, initial removal of two to three Glc moieties makes a routing signal with this glycan accessible. It is a molecular signal for vectorial transport of the respective glycoprotein from the ER to the Golgi. Delivery is performed by a cargo transporter $\left(\mathrm{M}_{\mathrm{r}} 53,000\right)$ present in the ER-Golgi intermediate compartment (ERGIC), called ERGIC53. ${ }^{105,106}$ Impairment of its binding to partially or fully deglucosylated $\mathrm{N}$-glycans of target glycoproteins by mutations in the ERGIC-53 gene or the gene of its luminal interaction partner, that is, the multiple coagulation factor deficiency protein 2, is cause of an autosomal recessive bleeding disorder characterized by combined reduction of blood levels of coagulation factors V and VIII. ${ }^{107-109}$ This case study of combined factors Vand VIII deficiency underlines the emerging relevance of glycan/lectin recognition for haemostasis.
Since the ER and the route from the ER to the Golgi are equipped with quality controls by lectins to sort out misfolded glycoproteins, glycans have more than one meaning already at this stage. ${ }^{110-112}$ Following the glycoprotein further along the Golgi route, each N-glycan can be trimmed to the pentasaccharide core as shown in - Fig. 2 so that, for example, complex-type structures arise from the ensuing maturation. In the Golgi, as shown in - Fig. 2, six GnTs are capable to add a GlcNAc residue at specific sites of the core pentasaccharide to initiate their synthesis. Incomplete maturation or restructuring by stepwise degradation of mature N-glycan branches are the means to let GlcNAc become presented for protein binding at branch ends.

Relevant for a route of platelet clearance, GlcNAc-terminating N-glycans of the GPIb $\alpha$ sub-unit of the von Willebrand factor (VWF) complex associate with the $\alpha_{\mathrm{M}^{-}}$-chain of the $\alpha_{M} \beta_{2}$-integrin of phagocytic cells (Mac-1, CD11b/CD18, CR3; Mac-1 was defined as granulocyte- and monocyte-specific antigen by a monoclonal antibody [clones M1/70] raised against mouse spleen cells ${ }^{113}$; for details on the Mac-2 antigen [clones M3/31 and M3/38], please see below). ${ }^{114,115}$ Terminal $\beta$ GlcNAc in N-glycans ( $\alpha$-anomeric linkage is known from mucins ${ }^{116}$ ) is not only a ligand for an integrin but also for the C-type lectins langerin (CD207), ${ }^{117,118}$ the liver and lymph node sinusoidal endothelial cell lectin (LSECtin) $^{119}$ and its close relative human dendritic cellspecific ICAM-3-grabbing nonintegrin-related protein (DCSIGNR, CD299 $)^{120}$ or its murine homologue SIGN-R2. ${ }^{121}$ The first epitope along the illustrated route of $\mathrm{N}$-glycan processing therefore fulfils the expectation for functional pairing.

Elongation of the $\mathrm{N}$-glycan chain by adding a Gal moiety (in 31,4 -linkage, as shown in the centre of - Fig. 4) drastically changes the ligand characteristics, underscoring the required specificity. As noted above, accessible Gal units are docking sites for hepatic clearance, and this also applies to coagulation factor VIII and to VWF $\mathrm{VW}^{122}$ or to tissue plasminogen activator. ${ }^{123}$ This type of interaction between desialylated glycoproteins on the surface of (senile) platelets and the hepatic asialoglycoprotein receptor is more than a clearance process. In fact, it is 'the long-elusive physiological ligandreceptor pair regulating hepatic thrombopoietin messenger ribonucleic acid production. ${ }^{124}$ Since the circulatory lifespan of platelets is shortened during systemic infection due to the activity of bacterial sialidases on cell surface glycans, the lectin-mediated clearance is a means of haemostatic adaptation limiting the severity of disseminated intravascular coagulation during sepsis. ${ }^{125}$ Physiologically, one means to mask this determinant (postal code) for hepatic uptake is by $\alpha 2,3$-sialylation ( - Fig. 4, top, left). Fittingly, engineered deficiency in a respective glycosyltransferase, that is, $\alpha 2,3-$ sialyltransferase-IV, accelerated clearance of these glycoproteins and hereby (likely) accounts for prolonged bleeding and coagulation times in the knockout (KO) mice. ${ }^{126}$ In contrast, the alternative to $\alpha 2,3$-sialylation, that is, $\alpha 2,6$-sialylation of $\mathrm{N}$-acetyllactosamine (LacNAc) shown in - Fig. 4, can be tolerated by the hepatic C-type lectin, as shown with neoglycoproteins and natural glycoproteins. ${ }^{127-129}$ Considering the frequent occurrence of LacNAc at the terminal position of 


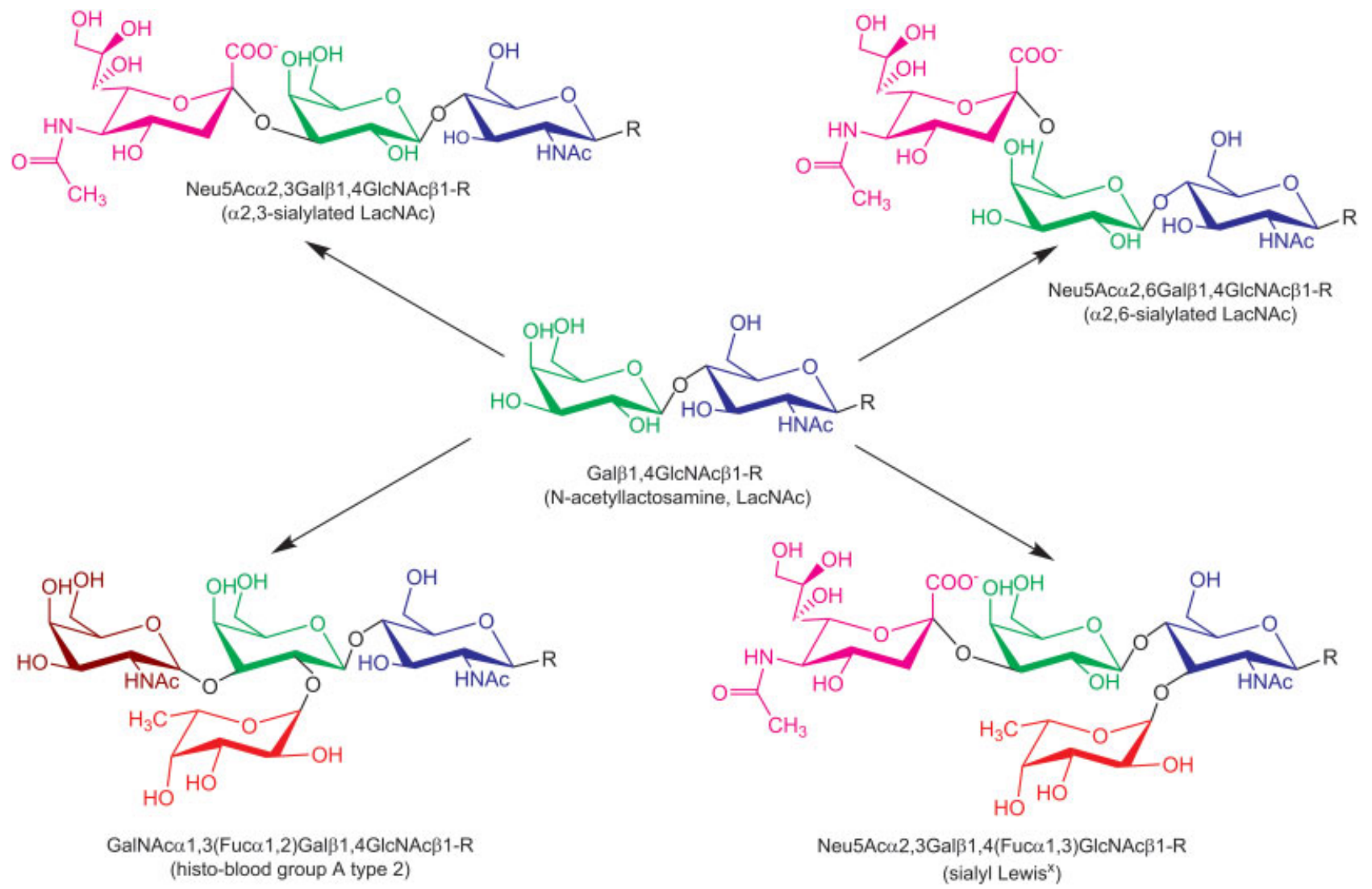

Fig. 4 Illustration of four different routes of biosynthetic elongation of a LacNAc epitope of complex-type N-glycans (centre). Specific glycosyltransferases can generate a panel of products (messages of distinct meaning), either by sialylation of terminal Gal in $\alpha 2,3-$ or in $\alpha 2,6-$ linkage (top part, left and right), by stepwise $\alpha 1,3$-fucosylation (of GlcNAc) and $\alpha 2,3$-sialylation (of Gal) to yield first the Lewis ${ }^{x}$ epitope (not shown) and then the shown sialyl Lewis ${ }^{x}\left(s^{x} e^{x}\right)$ tetrasaccharide (bottom part, right) or by a two-step reaction towards ABH histo-blood group (type 2) epitopes via $\alpha 1,2$-fucosylation (of Gal to yield the $\mathrm{H}(0)$ trisaccharide; not shown) and the following $\alpha 1,3-\mathrm{Gal}(\mathrm{NAc})$ addition (the $\alpha 1,3-$ GalNAc-containing A-type tetrasaccharide is shown: bottom part, left).

$\mathrm{N}$-glycans and its processing by these two different routes of sialylation shown in - Fig. $\mathbf{4}$ (top part), it is no surprise that, in addition to the C-type lectin fold, other types of lectins can accommodate these epitopes, especially the galectin and

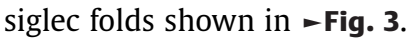

LacNAc is the canonical ligand for galectins. Its $\alpha 2,3-$ sialylation can enhance galectin affinity depending on the protein, most prominently for galectin-8. ${ }^{130}$ Of note, this galectin binds VWF and coagulation factor V, the latter then imported into megakaryocytes by endocytosis, and also to the platelet integrin $\alpha \operatorname{IIb} \beta_{3}$, a new entry to the list of platelet activators. ${ }^{131,132}$ Illustrating the marked impact of the site of sialic acid conjugation on ligand features, $\alpha 2,6$-sialylation switches off affinity to galectins, which bind LacNAc via hydrogen bonds to the axial 4'-OH and the exocyclic 6'-OH groups of the Gal moiety (please see - Fig. 1, second row for illustration of these positions, relative to the $3^{\prime}-\mathrm{OH}$ group). ${ }^{133}$ In the case of $\alpha 2,6$-sialylation of LacNAc shown in - Fig. 4 (top, right), the contact point at C6 is therefore occupied by a sialic acid residue. What is detrimental to galectin binding, though, is essential for association to siglecs. Presence of such a residue in $\alpha 2,3$-linkage is suited for siglec-4 (myelin-associated glycoprotein); when in $\alpha 2,6$ linkage, it is the docking site for siglec-2 (CD22). In sum, $\alpha 2,6-$ sialylation of LacNAc extension thus abolishes affinity to galectins, can be tolerated by a C-type lectin and is the primary contact to a siglec. By the way, sialic acids can hereby implement recognition sites on glycoproteins for a siglec so that a contribution to the regulation of their plasma levels is possible, as discussed for VWF and coagulation factor VIII by binding to siglec- 5 on macrophages. ${ }^{134}$

The two other illustrated products of terminal $\mathrm{N}$-glycan tailoring shown in $\boldsymbol{F}$ Fig. 4 (bottom), that is, the histo-blood group A determinant ( $\mathbf{- F i g . 4}$, bottom, left) or (sialyl) Lewis ${ }^{\mathrm{x}}$ $\left[(\mathrm{s}) \mathrm{Le}^{\mathrm{x}}, \mathrm{CD} 15(\mathrm{~s})\right]$ (-Fig. 4, bottom, right), too, have their specific meaning as ligand. For example, galectin-3 (the mentioned Mac-2 antigen; please see below) is a highaffinity receptor of the A-tetrasaccharide, ${ }^{135}$ DC-SIGN (CD209) a receptor of epitopes of the Lewis blood group system such as Le $\mathrm{Lr}^{\mathrm{a}} \mathrm{Le}^{\mathrm{x} 136}$ and the selectins bind the shown $\mathrm{sLe}^{\mathrm{x}}$, an interaction of pivotal significance for the interaction of leukocytes and platelets with the vasculature under conditions of activation (please see below). ${ }^{137,138}$ Turning Le $^{\mathrm{x}}$ not into $\mathrm{SLe}^{\mathrm{x}}$ but alternatively into Le $\mathrm{L}^{\mathrm{y}}$ (CD174) by terminal $\alpha 1,2$-fucosylation instead of the $\alpha 2,3$-sialylation shown in - Fig. 4 renders the respective $\mathrm{N}$-glycan capable to interact with thrombomodulin's C-type lectin-like domain, implicated in inhibiting angiogenesis. ${ }^{139}$ 


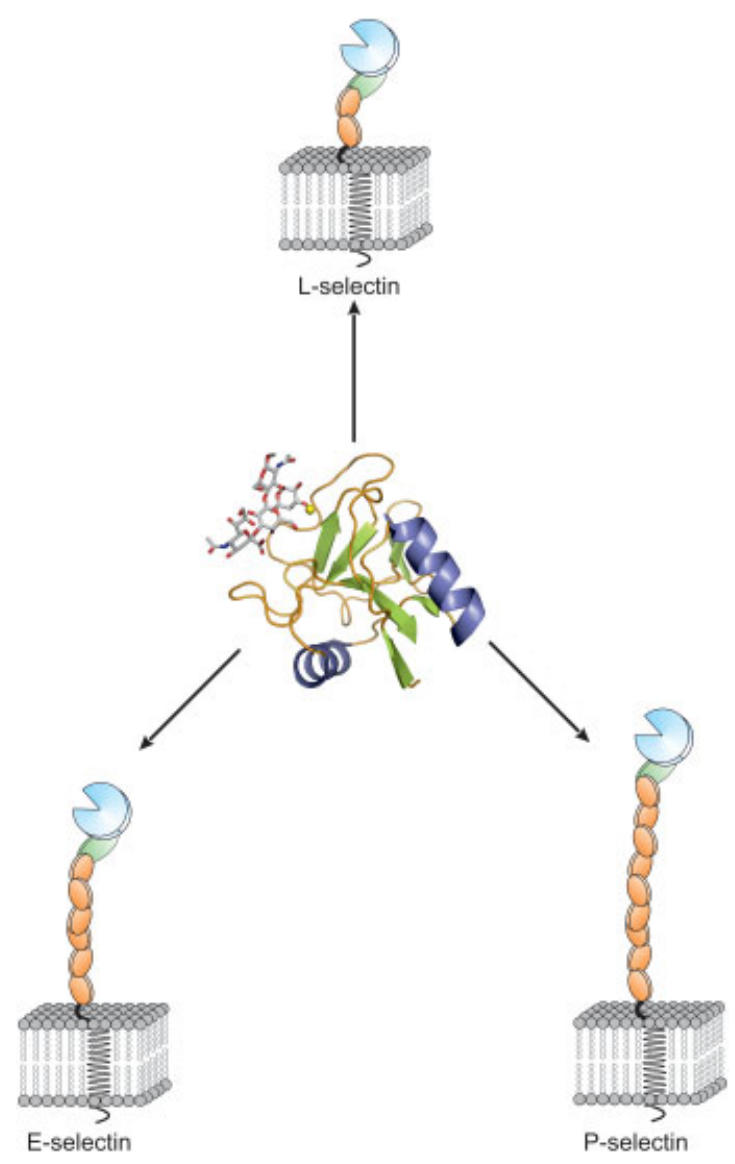

Fig. 5 Modular organization of the three selectins characterized by the C-type lectin domain (centre; please see also - Fig. 3A) at the most prominent position for intercellular contact, followed by an epidermal growth factor (EGF)-like domain and two to nine complement-binding consensus repeats.

The three selectins mentioned above are classical examples of lectins with modular architecture. Their design is shown in -Fig. 5. The terminal C-type CRD, as is the case for the $\mathrm{V}$-set IgG domain of siglec rods, is optimally presented on the membrane to bridge cells. First detected by function blocking or localization using monoclonal antibodies (Mel14) for the lymphocyte homing receptor L-selectin (CD62L), ${ }^{140} \mathrm{H} 18 / 7$ and H4/18 for the chemokine- and endotoxin-inducible endothelial-leukocyte adhesion molecule-1 (ELAM-1; E-selectin, CD62E) ${ }^{141}$ and S12 for an $\alpha$-granule membrane protein of $M_{r} 140,000$ (GMP-140) that is redistributed to the plasma membrane upon platelet stimulation, what gave GMP-140 a new name: platelet activationdependent granule to external membrane protein (PADGEM; P-selectin, CD62P). ${ }^{142-145}$ The spatial accessibility of the glycan counter-receptors at branch ends, rapid on-rates during contact formation by mostly ionic interactions and catch bonding are factors that underlie their role as selective cell adhesion molecules (explaining the origin of the term selectin ${ }^{146}$ ), operating as anchors for cells in the blood flow. Like the mentioned enzymatic removal of Fuc from the lymphocyte surface raised evidence for the concept of glycans as postal codes in routing and delivery, ${ }^{18}$ the importance of a second sugar type present in sLe $\mathrm{a}^{\mathrm{a} / \mathrm{x}}$ epitopes, that is, sialic acids, has been revealed by treatment of sections of lymphoid organs with bacterial sialidase. ${ }^{147}$ These reports converge to support the involvement of glycans in lymphocyte homing, as the blocking experiments with selectinbinding monoclonal antibodies did for the protein side. Intriguingly, $\alpha$-L-fucosidase is suggested to limit leukocyte migration at late stages of inflammation (tested in murine experimental autoimmune uveoretinitis) upon induction by chemokines CCL3/5 by reducing P-selectin binding. ${ }^{148}$ Besides presentation by $\mathrm{N}$-glycans, the sLe $^{\mathrm{a} / \mathrm{x}}$ epitopes are characteristically also a part of certain types of mucin-type O-glycans, here reaching a high density that favours to build and maintain selectin-glycoprotein contacts. In addition to the negative charge of the sialic acid, sulphate groups at C6 of Gal and/or GlcNAc moieties increase the ligand's capacity for rapid contact building via ionic charge complementarity under conditions of flow. ${ }^{149-153}$ Sulphation is also conducive to 'write' a routing signal for glycoprotein clearance, if GlcNAc is not conjugated with Gal but with N-acetylgalactosamine (GalNAc), a further mode of N-glycan tailoring. ${ }^{154}$

Before turning to mucin-type O-glycans in more detail, a second salient lesson should be drawn from - Fig. 4, besides the documented sets of structure-ligand relationships: a glycan epitope (such as LacNAc), that is, a certain acceptor, can be converted into more than one product. This opens opportunities for highly versatile regulation of glycome representation by modulating enzyme and/or substrate availability. Exemplifying the intimate connection of a distinct biomedically relevant process with glycosylation, the malignancyassociated high-level sialylation can be interpreted, among other implications, as a protection against growth inhibition. Along this line, the tumour suppressor $\mathrm{p} 16^{\text {INK4a }}$ has been shown to counteract malignancy at this level. This protein is essential to induce anoikis in human pancreatic carcinoma (Capan-1) cells. It works via orchestrated down-regulation of $\alpha 2,6$-sialylation (by reducing sialic acid biosynthesis) teamed up with up-regulation of homobivalent galectin-1, which is the functional receptor 'reading' the increase in terminal LacNAc and cross-linking the similarly up-regulated glycoprotein counter-receptor $\alpha_{5} \beta_{1}$-integrin via this recognition to trigger caspase- 8 activation. ${ }^{155,156}$

The signal (access to LacNAc), the 'reader' (galectin-1) and the downstream effector ( $\alpha_{5} \beta_{1}$-integrin) are thus co-regulated towards anoikis induction, giving the glycophenotypic change a functional meaning. Of note, a similar team building to attain $\mathrm{T}$ cell apoptosis has been reported for $\alpha 2,6$-sialyltransferase, CD45 and galectin- $1 .^{157}$ The respective delineation of regulatory pathways for generating selectin counterreceptors ${ }^{158-160}$ has proven to be a hallmark of supporting the concept of functionally dynamic glycomics in lymphocyte homing and platelet aggregation. On the level of $\mathrm{O}-$ glycans, counter-receptor occurrence can be as tightly controlled in a coordinated manner by competition between different routes and terminal tailoring, following the same principles as shown in -Fig. 4 for N-glycans. Routes of mucin-type 0 -glycan processing after the initial incorporation of a GalNAc residue into the protein are illustrated in -Fig. 6. The presence of the $\alpha$-linked GalNAc residue 

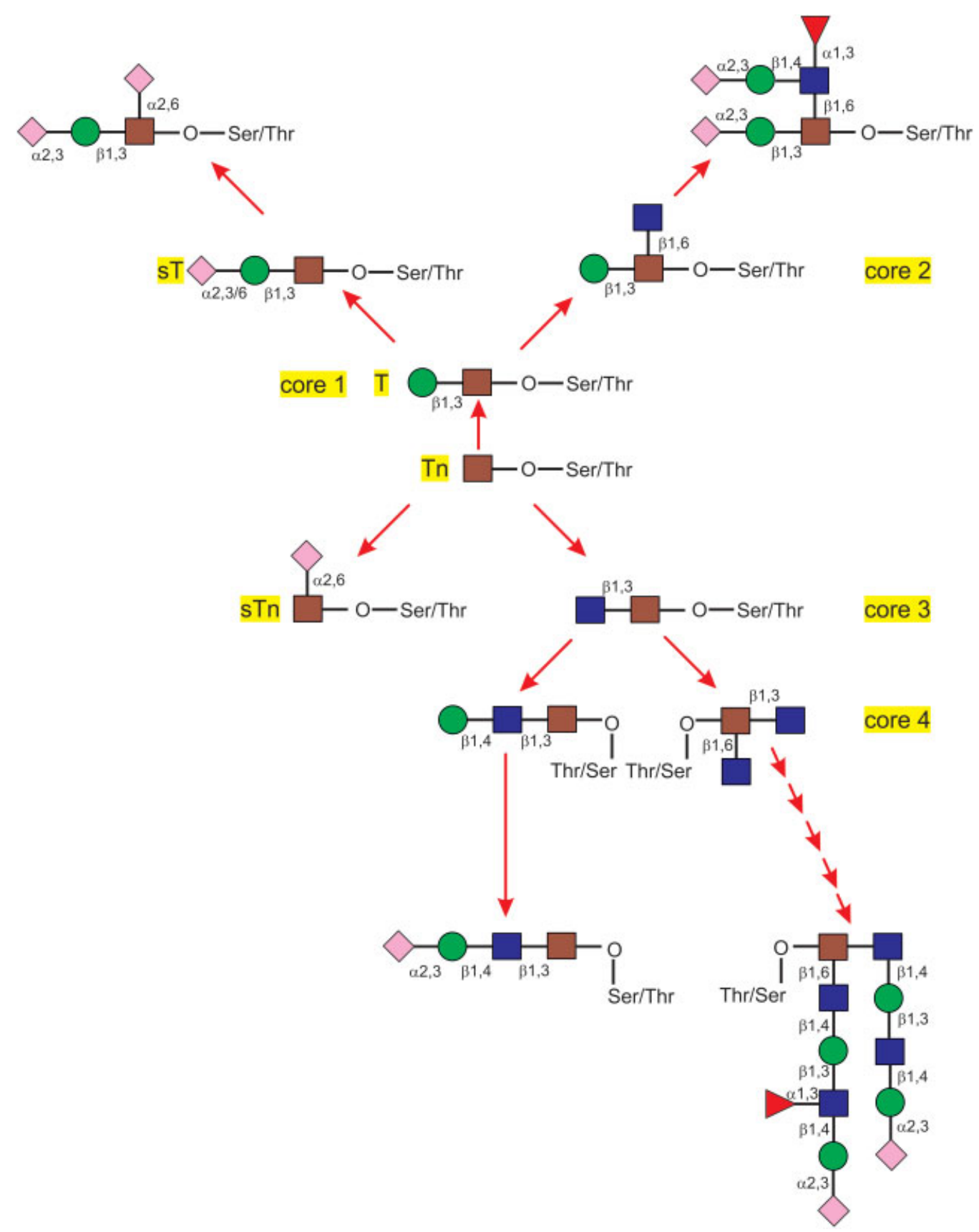

Fig. 6 Illustration of six different routes of biosynthetic elongation of the first product of mucin-type O-glycosylation, i.e., $T_{n}$ antigen (centre). $\alpha 2,6$-Sialylation of the GaINAc residue results in the sialyl (s) $T_{n}$ determinant that cannot undergo any further processing. The activity of the respective sialyltransferases underlies occurrence of $s T_{n}$ at the expense of all other O-glycans. Extension of the $T_{n}$ antigen towards branched structures can alternatively proceed along two routes that establish either the core 1 or the core 3 structures. Enzymatic $\beta 1,3$-galactosylation produces the core 1 disaccharide ( $T$ antigen) that can be sialylated stepwise in up to two positions, first in $\alpha 2,3$-linkage at the Gal moiety to yield the sialyl (s)T antigen, finally in $\alpha 2,6$-linkage at the GalNAc residue to produce disialylated T (top part, left). Alternatively, the T antigen can be subject to core 2 trisaccharide generation by adding GlcNAc at the central GalNAc residue in $\beta 1,6$-linkage (top part, right). As shown in - Fig. 2 and in - Fig. 4 for N-glycans, this GlcNAc residue is the starting point of branch elongation that can encompass LacNAc repeats and the Le/sLe determinants. This trisaccharide therefore is the platform for obtaining various types of oligosaccharides, depending on the actual availability of enzymes and substrates for the competing routes of processing. Mechanistically, the same holds true for the case of transition of the $T_{n}$ antigen to the core 3 disaccharide and then core 4 structures (bottom part, right), in close analogy to core 1 and core 2 synthesis. Correspondingly, without branch introduction, the core 3 disaccharide can be extended in two steps to a sialylated tetrasaccharide (bottom part, centre), in analogy to core 1 oligosaccharide processing. Occurrence of $\alpha 2,3$-sialylated LacNAc in fully processed core $1 / 3$ structures resembles that of a complex-type $\mathrm{N}$-glycan branch ends (please see - Fig. 4, top part, left). When considering that the processing of a $\mathrm{T}_{\mathrm{n}}$ antigen can take diverse routes, it becomes obvious that the system of mucin-type O-glycosylation has manifold possibilities to generate a large number of O-glycans by regulating acceptor, enzyme and/or substrate levels. For explanation of symbols for sugars, please see legend to - Fig. 1. 
defines the $T_{n}$ antigen ( $n$ for nouvelle; CD175), the target of serum auto-antibodies en route to spontaneous polyagglutinability of erythrocytes in the cold causing the $T_{n}$ syndrome. $^{161-163}$ This determinant is not only a docking site for antibodies but also for human lectins.

\section{Functional Pairing: Mucin-Type O-Glycans}

This type of protein glycosylation is characterized by reaching a high local density, ideal for a defensive barrier and also for high-affinity receptor binding. ${ }^{164-167}$ The committed step for mucin-type O-glycosylation is performed by members of the family of polypeptide $\mathrm{N}$-acetylgalactosaminyltransferases (GalNAcTs), most of the 20 enzymes harbouring a $\beta$-trefoil lectin domain that binds GalNAc in addition to the enzymatically active protein part. ${ }^{32,33,168}$ They cooperate to let GalNAc incorporation reach diverse levels of local density in their substrates, and more than $80 \%$ of the proteins passing through the Golgi are predicted to be processed this way. Interestingly, each enzyme can well fulfil a particular functional role, as revealed by KO mouse analysis. Despite integrity of all other enzymes, a deficiency in one of the $\mathrm{N}$-acetylgalactosaminyltransferases, that is, GalNAcT-1, caused a moderate to severe bleeding disorder due to reduced blood levels of coagulation factors and decreased level of recruitment of leukocytes to sites of inflammation, highlighting O-glycan relevance to haemostasis and vascular biology. ${ }^{169}$ Binding studies of $\mathrm{T}_{\mathrm{n}}$ presenting glycopeptides demonstrated that O-linked GalNAc is a ligand for endogenous lectins. The macrophage Gal(-binding C)-type lectin (MGL, CD301, CLEC10A) and galectin-4 are tissue receptors of the $T_{n}$ antigen. ${ }^{170,171}$ Present in Kupffer cells that also express the mentioned $\alpha_{\mathrm{M}} \beta_{2}$-integrin for $\beta$-GlcNAcdependent platelet clearance, a C-type lectin (CLEC4F) is responsible for efficient uptake of $T_{n}$-presenting mucins and of platelets of genetically engineered mice made defective in O-glycan maturation so that this process is entirely arrested at the stage of O-GalNAc presentation. ${ }^{172,173}$ Physiologically, this epitope is obliterated for this process by $\alpha 2,6$-sialylation. The resulting disaccharide sialyl $\mathrm{T}_{\mathrm{n}}\left(\mathrm{sT}_{\mathrm{n}} ; \mathrm{CD} 175 \mathrm{~s}\right)$ shown in - Fig. 6 maintains affinity for human MGL, ${ }^{174}$ as is the case for $\alpha 2,6$ sialylated LacNAc at $\mathrm{N}$-glycan termini and the closely related hepatic C-type lectin (please see above). At the same time, the sialylation step enables a gain-of-function, because it confers binding to siglec-15 on macrophages. ${ }^{175,176} \mathrm{~A}$ V-set module resembling that of siglecs in a paired Ig-like receptor, that is, PILR $\alpha$, also binds the $\mathrm{sT}_{\mathrm{n}}$ antigen. ${ }^{177,178}$

Sialylation of the $T_{n}$ epitope is not the only way to use it as substrate. As shown in - Fig. 6, an alternative pathway, competing with the synthesis of the $\mathrm{sT}_{\mathrm{n}}$ antigen, is the generation of the $\mathrm{T}(\mathrm{F})$ disaccharide (CD176; first described as antigen by $\mathrm{O}$. Thomsen and his assistant $\mathrm{V}$. Friedenreich, thus termed Thomsen-Friedenreich antigen ${ }^{179}$ ), the core 1 disaccharide of mucin-type 0-glycans. Dense clustering favours binding of galectins-3 and $-4 .^{180,181}$ Its sialylation in $\alpha 2,3-$ linkage renders binding to galectin- $8^{130}$ and siglecs, especially sialoadhesin (siglec- 1$)^{182}$ and siglec-9, ${ }^{183}$ possible, disialylation (at the Gal and GalNAc moieties) to siglec- $4 .{ }^{184}$ In the framework of the system of O-glycosylation, the $\alpha 2,3$-sialyla- tion of the core 1 disaccharide precludes its branching to yield core 2 glycans, as core 1 disaccharide synthesis makes core 4 production impossible ( - Fig. 6 ). Of fundamental importance, the decisions made by committing steps at the various stages highlight the broadness of the glycan panel and the enormous adaptability of the glycan profile, strongly suggesting their influence on regulating cellular activities. Core 2 branching and sLe ${ }^{\mathrm{x}}$ production, as shown in -Fig. $\mathbf{6}$, are steps to build selectin counter-receptors such as sLe ${ }^{\mathrm{x}}$ noted above. Interestingly, the Golgi-resident sialyltransferase-IV-dependent final step of sLe ${ }^{\mathrm{x}}$ synthesis has also been revealed to be important for chemokine (CCL3 and CCL4) binding to the CCR5 receptor $^{185}$ and for CXCR-2-triggered firm leukocyte arrest after CXCL1/CXCL8 injection in cremaster muscle venules. ${ }^{186,187}$

Looking at regulation of galectin binding to mucin-type O-glycans more closely, an analogy can be drawn to the concerted actions described above for $\mathrm{N}$-glycan $\alpha 2$,6-sialylation and galectin-1. Decisions between routes of synthesis explain how growth-regulatory processes are switched on or off. $181,188,189$ The role as a metastasis suppressor of the glycosyltransferase $\mathrm{N}$-acetylgalactosaminide $\alpha 2,6$-sialyltransferase-2 (ST6GalNAcT-2) in breast cancer had been attributed to reduced $\mathrm{T}(\mathrm{F})$ disaccharide presence that lowers breast tumour cell aggregation and retention at metastatic sites via galectin-3. ${ }^{190}$ Effectively, this type of $\alpha 2,6$-sialylation diverts product generation from reaching, for example, core 1 to $\mathrm{sT}_{\mathrm{n}}$, as shown in - Fig. $\mathbf{6}$ and already mentioned above. Convergent effects on extent of presence of this disaccharide by altering its status of $\alpha 2,6$-sialylation and core 2 branching, too, favour lung cancer formation. 191

Next, like selectins, galectins can home in on branched Oglycans, selectins to the $S \mathrm{Le}^{\mathrm{a} / \mathrm{x}}$ termini, especially galectins- 1 and -3 to the internal LacNAc repeats of the $\beta 1,6$-branch. Susceptibility of activated T cells, ${ }^{192}$ lymphoma cells ${ }^{193}$ and prostate (LNCaP) carcinoma cells ${ }^{194}$ to apoptosis induction by galectin- 1 and impairment of natural killer cell activation by the binding of galectin- 3 to tumour cells ${ }^{195}$ are examples for the significance of galectin pairing with this part of the $\beta 1,6$ linked branch of extended core 20 -glycans shown in - Fig. 6 . Branch extension (and terminal tailoring by fucosylation, sialylation and sulphation to obtain sulphated sLe ${ }^{\mathrm{a} / \mathrm{x}}$ epitopes) is thus crucial to convey the signal for lectin binding.

In aggregate, any modulation in enzyme, substrate and acceptor availability can shift the relative proportions of the products, as can be deduced from - Figs. 4 and $\mathbf{6}$ (for gangliosides as counter-receptors of tissue lectins, please see Ref. 196; for glycan-glycan interactions, please see Ref. 197). Considering occurrence of competition for an acceptor at different sites of the illustrated pathways of $\mathrm{N}$ - and mucintype O-glycosylation, the extent of impact is not fixed but regulatable. As a consequence, cellular responsiveness to tissue lectins is intimately tunable, giving a functional dimension to the noted complexity of the glycome. Clearly, the potential for regulatory events will be broadened, if the lectin side is also a platform for fine-tuning, at the levels of presence and of structural design. The mentioned diversification of an ancestral gene is a main route towards this aim, and $\boldsymbol{- F i g .} \mathbf{5}$ documents changes in the length of the stalk 
among the three selectins. Molecular diversity can also be achieved (1) by sequence changes in the CRD affecting the profile of ligands among members of a family and (2) by alterations of the modular design. Hereby, emergence of functional antagonism due to differences in modular design is possible. For this case, galectins- 1 and -3 serve as role model, as already mentioned above. ${ }^{101,198}$ This emerging concept of functional crosstalk is a driving force to characterize in detail the lectins' structures, and this work raises awareness to address a fundamental question: what is the significance of modular architecture? Whereas lectins with trans-membrane sections such as selectins (please see - Fig. 5) are ideal for cell-cell bridging, the situation is much less clear for lectins without such a module.

\section{Lectin Diversity: The Example of Galectins}

Vertebrate adhesion/growth-regulatory galectins are organized in three types of modular architecture ( - Fig. 7 ). The manifestation of a strict selection process towards the three illustrated forms serves as instructive case for further work to answer the given question. As common approach of structural analysis, crystallography has been brought to its limits for the galectins.

Whereas the prototype (homodimeric) galectins and most CRDs obtained by engineering could readily be analysed by crystallography, often in complex with ligands and even within a broad range of $\mathrm{pH}$ values, ${ }^{133,199}$ intra-molecular dynamics of the tandem-repeat- and chimera-type proteins is a likely reason that precluded obtaining crystals for the full-length proteins of these two groups. Recently, partial truncation of the $\mathrm{N}$-terminal segment of human galectin-3 by engineering facilitated to take structural analysis of crystals beyond the CRD. ${ }^{200,201}$ Like the three selectins, this galectin had first been detected by monoclonal antibodies (clones M3/31 and $\mathrm{M} 3 / 38),{ }^{202}$ immunohistochemically present in macrophages, dendritic cells and in epithelium, thus termed the Mac-2 antigen. ${ }^{203-205}$ Its ligand spectrum covers glycans and proteins, ${ }^{206}$ its trimodular design shown in -Fig. 7 enables aggregation to oligomers via contacts between the $\mathrm{N}$-terminal tails and/or the CRDs in the presence of multivalent ligand ${ }^{207-210}$; please see Flores-Ibarra et $\mathrm{al}^{201}$ for review of the literature). This manifestation of a strict selection process towards the three forms shown in - Fig. $\mathbf{7}$ is not only a suited test model, but it also inspires routes to redesign nature to clarify structure-activity relationships.

Looking at an involvement of galectin-3 in thrombosis, together with its counter-receptor galectin-3-binding protein (Mac-2 BP/90K; an adhesion mediator interacting with $\beta_{1}$-integrin sub-units, fibronectin, nidogen and collagens IV$\mathrm{VI}),{ }^{211-213}$ it has been suggested to play a critical role in venous thrombosis. ${ }^{214}$ The appearance of Mac-2 $\mathrm{BP} / 90 \mathrm{~K}$ as contaminant in preparations of recombinant coagulation factor IX was therefore judged to be cause of 'unforeseen consequences'. ${ }^{215}$ Its pro-inflammatory signalling function is not only active in osteoarthritis pathogenesis, ${ }^{102}$ but, for example, also locally in unstable plaque regions of carotid endarterectomy ${ }^{216}$ or rheumatoid synovium. ${ }^{217}$ The molecular and topological nature of the active galectin-counterreceptor lattice for outside-in signalling remains to be defined. As the role of the recently discovered appearance of galectin-3' CRD in heterodimers with prototype CRDs ${ }^{218}$ warrants elucidation.

When comparing the design of the homo-/hetero-bivalent family members, the structural difference between the noncovalent homodimers and the heterodimers with linker peptides between the two different CRDs is clear. However, the relationship from structure (e.g. type of CRD or length of linker) to function is again largely unexplored. Here, the combination of rational protein engineering, for example, turning galectin- 1 into a covalently associated variant connected by the linker of a tandem-repeat-type galectin, ${ }^{219}$ with activity assays, for example, platelet activation with galectin- 8 as positive control, offers an attractive approach

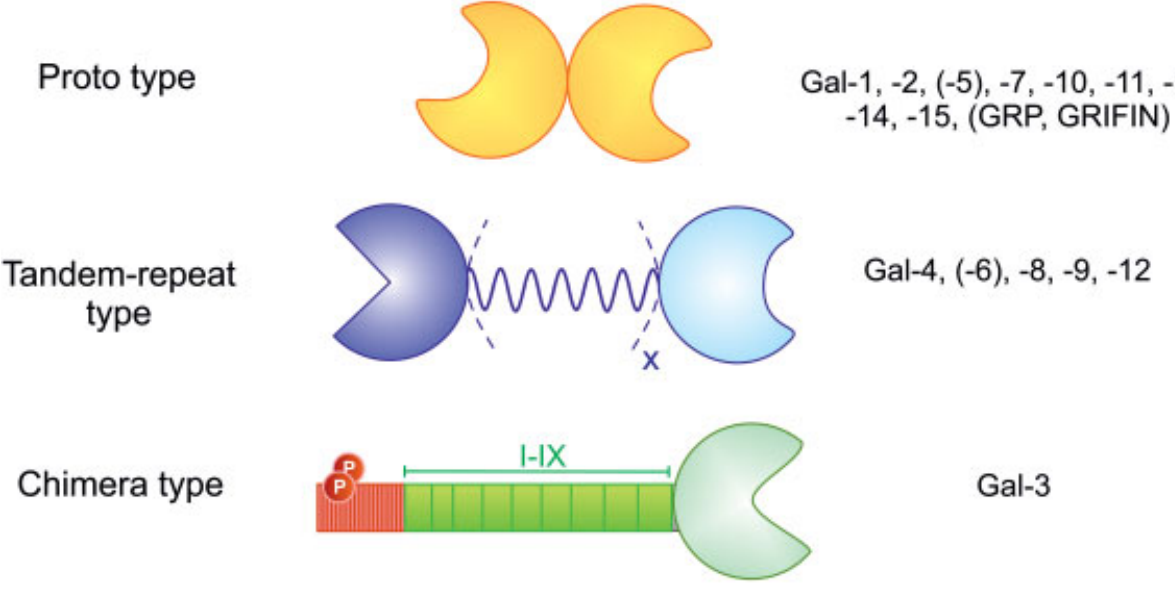

Fig. 7 Illustration of the three types of modular architecture of vertebrate galectins, i.e., non-covalent association of two identical carbohydrate recognition domains (CRDs) to a homodimer (prototype), covalent association (by a linker of distinct length; it differs between galectins, and alternative splicing brings about length variation in certain cases, e.g. galectin-8 with two lengths at 33 or 75 amino acids) of two different CRDs (tandem-repeat type) and the trimodular product of $\mathrm{N}$-terminal association of a peptide with two sites for serine phosphorylation, a repeat region of non-triple-helical collagen-like peptides (nine in human galectin-3) and the canonical CRD, termed chimera type, with listing of the respective numbers/acronyms in the galectin nomenclature in each group (right side). 
for thorough analysis, with the perspective to develop innovative antagonists or agonists on the platform of human galectins and beyond.

\section{Conclusion}

In retrospect, there has been 'the widely held belief that carbohydrates are dull compounds, and that they serve only as structural or protective materials (e.g. cellulose in plants and chitin in insects) and as an energy source (glycogen in animals), but lack any biological specificity. The possibility that living organisms form a myriad of compounds in which carbohydrate is covalently linked to protein, with the carbohydrate having manifold functions, was ignored by most chemists and biochemists alike'. ${ }^{220}$ Ironically, when it was realized, the exceptionally demanding character of the task to handle analysis of glycans, called complex carbohydrates for a long time, required enormous efforts to begin reaching firm conclusions on structure-activity relations.

Our introductory focus on the amazing structural talents of carbohydrates to accomplish high-density coding has laid the foundation to understand the paradigmatic change in the way glycans are viewed. The convergence of the great strides made in glycan analysis with discovering a matching diversity of endogenous receptors (lectins) explains why the field of functional glycomics evolved rapidly in the last decades. Much as glycophenotyping with plant lectins, now also done with tissue lectins, has been a boon for sensing the dynamics and spatiotemporal control of representation of distinct glycan epitopes, ${ }^{221-227}$ the concept of their functional pairing with endogenous receptors is becoming a gateway towards understanding the workings of this aspect of the sugar code. The case study of the selectins has already taught the amazing lesson that platelet activation and inflammatory stimuli set genetic reprogramming and transport processes in motion to let functional pairing happen at the right place and at the right time, and selectins as representatives of C-type lectins are not alone.

The range of tissue lectins revealed to be involved in the mentioned processes is steadily growing, underscoring the nature of glycans as biochemical messages, as noted for inflammation. ${ }^{228}$ The co-evolution of messages (glycans) and readers (lectins) as well as their apparently intimately orchestrated expression justify the term 'third alphabet of life' for carbohydrates shown in -Fig. $\mathbf{1}$.

With these central points made, it is reasonable to advise that the possibility of functional activity of the glycans should be considered, when dealing with a glycoprotein. Looking, for example, at the glycoprotein VWF, C-type lectins, a siglec and galectins are capable to home in on its glycan(s) (for overview of VWF binders, please see Ref. 229), and new aspects in the field of lectins are being connected to haemostasis, for example, the lectin pathway of complement activation in crosstalk to coagulation. ${ }^{230,231}$ Among the open challenges thus are a delineation of counter-receptors for lectins as well as of lectin networking within and between families, hereby deservedly putting members of families beyond selectins firmly on the map of receptors acting in concert in haemostasis and thrombosis.
Conflict of Interest

None declared.

\section{Acknowledgements}

We gratefully acknowledge inspiring discussions with Drs. B. Friday and A. Leddoz.

\section{References}

1 Gabius H-J, ed. The Sugar Code. Fundamentals of Glycosciences. Weinheim, Germany: Wiley-VCH; 2009

2 Bennett HS. Morphological aspects of extracellular polysaccharides. J Histochem Cytochem 1963;11:14-23

3 Bettelheim-Jevons FR. Protein-carbohydrate complexes. Adv Protein Chem 1958;13:35-105

4 Klenk E. On the discovery and chemistry of neuraminic acid and gangliosides. Chem Phys Lipids 1970;5(01):193-197

5 Sharon N. Complex Carbohydrates. Their Chemistry, Biosynthesis, and Functions. Reading, MA: Addison-Wesley Publ. Co.; 1975

6 Montreuil J. The history of glycoprotein research, a personal view. In: Montreuil J, Vliegenthart JFG, Schachter H, eds. Glycoproteins. Amsterdam, The Netherlands: Elsevier; 1995:1-12

7 Reuter G, Gabius H-J. Eukaryotic glycosylation: whim of nature or multipurpose tool? Cell Mol Life Sci 1999;55(03):368-422

8 Buddecke E. Proteoglycans. In: Gabius H-J, ed. The Sugar Code. Fundamentals of Glycosciences. Weinheim, Germany: Wiley-VCH; 2009:199-216

9 Merzendorfer H. Chitin: structure, function and metabolism. In: Gabius H-J, ed. The Sugar Code. Fundamentals of Glycosciences. Weinheim, Germany: Wiley-VCH; 2009:217-229

10 Corfield AP, Berry M. Glycan variation and evolution in the eukaryotes. Trends Biochem Sci 2015;40(07):351-359

11 Tan FY, Tang CM, Exley RM. Sugar coating: bacterial protein glycosylation and host-microbe interactions. Trends Biochem Sci 2015;40(07):342-350

12 Corfield A. Eukaryotic protein glycosylation: a primer for histochemists and cell biologists. Histochem Cell Biol 2017;147(02):119-147

13 Kopitz J. Lipid glycosylation: a primer for histochemists and cell biologists. Histochem Cell Biol 2017;147(02):175-198

14 Schnaar RL, Lopez PHH. Preface and ganglioside nomenclature. Prog Mol Biol Transl Sci 2018;156:xvii-xxi

15 Laine RA. The information-storing potential of the sugar code. In: Gabius H-J, Gabius S, eds. Glycosciences: Status and Perspectives. London, UK and Weinheim, Germany: Chapman \& Hall; 1997:1-14

16 Roseman S. Reflections on glycobiology. J Biol Chem 2001;276 (45):41527-41542

17 Kornfeld S. A lifetime of adventures in glycobiology. Annu Rev Biochem 2018;87:1-21

18 Gesner BM, Ginsburg V. Effect of glycosidases on the fate of transfused lymphocytes. Proc Natl Acad Sci US A 1964;52:750-755

19 Morell AG, Irvine RA, Sternlieb I, Scheinberg IH, Ashwell G. Physical and chemical studies on ceruloplasmin. V. Metabolic studies on sialic acid-free ceruloplasmin in vivo. J Biol Chem 1968;243(01):155-159

20 Roseman S. The synthesis of complex carbohydrates by multiglycosyltransferase systems and their potential function in intercellular adhesion. Chem Phys Lipids 1970;5(01):270-297

21 Winterburn PJ, Phelps CF. The significance of glycosylated proteins. Nature 1972;236(5343):147-151

22 Brockhausen I, Schachter H. Glycosyltransferases involved in N-and O-glycan biosynthesis. In: Gabius H-J, Gabius S, eds. Glycosciences: Status and Perspectives. London, UK and Weinheim, Germany: Chapman \& Hall; 1997:79-113

23 Sears P, Wong C-H. Enzyme action in glycoprotein synthesis. Cell Mol Life Sci 1998;54(03):223-252

24 Endo T. O-mannosyl glycans in mammals. Biochim Biophys Acta 1999;1473(01):237-246 
25 Dall'Olio F, Chiricolo M. Sialyltransferases in cancer. Glycoconj J 2001;18(11-12):841-850

26 Harduin-Lepers A, Mollicone R, Delannoy P, Oriol R. The animal sialyltransferases and sialyltransferase-related genes: a phylogenetic approach. Glycobiology 2005;15(08):805-817

27 Patsos G, Corfield A. O-Glycosylation: structural diversity and function. In: Gabius H-J, ed. The Sugar Code. Fundamentals of Glycosciences. Weinheim, Germany: Wiley-VCH; 2009:111-137

28 Wilson IBH, Paschinger H, Rendic D. Glycosylation of model and 'lower' organisms. In: Gabius H-J, ed. The Sugar Code. Fundamentals of Glycosciences. Weinheim, Germany: Wiley-VCH; 2009:139-154

29 Zuber C, Roth J. N-Glycosylation. In: Gabius H-J, ed. The Sugar Code. Fundamentals of Glycosciences. Weinheim, Germany: Wiley-VCH; 2009:87-110

30 Takashima S, Tsuji S. Functional diversity of mammalian sialyltransferases. Trends Glycosci Glycotechnol 2011;23(132):178-193

31 Aplin JD, Jones CJ. Fucose, placental evolution and the glycocode. Glycobiology 2012;22(04):470-478

32 Bennett EP, Mandel U, Clausen H, Gerken TA, Fritz TA, Tabak LA. Control of mucin-type O-glycosylation: a classification of the polypeptide GalNAc-transferase gene family. Glycobiology 2012; 22(06):736-756

33 Raman J, Guan Y, Perrine CL, Gerken TA, Tabak LA. UDP-N-acetyl$\alpha$-D-galactosamine:polypeptide N-acetylgalactosaminyltransferases: completion of the family tree. Glycobiology 2012;22 (06):768-777

34 Togayachi A, Narimatsu H. Functional analysis of $\beta 1,3-N$-acetylglucosaminyltransferases and regulation of immunological function by polylactosamine. Trends Glycosci Glycotechnol 2012;24(137):95-111

35 Hennet T, Cabalzar J. Congenital disorders of glycosylation: a concise chart of glycocalyx dysfunction. Trends Biochem Sci 2015;40(07):377-384

36 Schengrund C-L. Gangliosides: glycosphingolipids essential for normal neural development and function. Trends Biochem Sci 2015;40(07):397-406

37 Bhide GP, Colley KJ. Sialylation of N-glycans: mechanism, cellular compartmentalization and function. Histochem Cell Biol 2017; 147(02):149-174

38 Honke K, Taniguchi N. Animal models to delineate glycan functionality. In: Gabius H-J, ed. The Sugar Code. Fundamentals of Glycosciences. Weinheim, Germany: Wiley-VCH; 2009:385-401

39 Takamatsu S, Antonopoulos A, Ohtsubo K, et al. Physiological and glycomic characterization of $\mathrm{N}$-acetylglucosaminyltransferase-IVa and-IVb double deficient mice. Glycobiology 2010;20(04):485-497

40 Ohtsubo K. Biological significance of $\mathrm{N}$-acetylglucosaminyltransferase-IV-mediated protein glycosylation on the homeostasis of cellular physiological functions. Trends Glycosci Glycotechnol 2011;23(130):103-105

41 Roth J. Subcellular organization of glycosylation in mammalian cells. Biochim Biophys Acta 1987;906(03):405-436

42 Varki A. Factors controlling the glycosylation potential of the Golgi apparatus. Trends Cell Biol 1998;8(01):34-40

43 Gabius H-J, André S, Kaltner H, Siebert HC. The sugar code: functional lectinomics. Biochim Biophys Acta 2002;1572(23):165-177

44 Cummings RD. The repertoire of glycan determinants in the human glycome. Mol Biosyst 2009;5(10):1087-1104

45 Moremen KW, Tiemeyer M, Nairn AV. Vertebrate protein glycosylation: diversity, synthesis and function. Nat Rev Mol Cell Biol 2012;13(07):448-462

46 Manning JC, Romero A, Habermann FA, García Caballero G, Kaltner H, Gabius HJ. Lectins: a primer for histochemists and cell biologists. Histochem Cell Biol 2017;147(02):199-222

47 Kaltner H, García Caballero G, Ludwig A-K, Manning JC, Gabius HJ. From glycophenotyping by (plant) lectin histochemistry to defining functionality of glycans by pairing with endogenous lectins. Histochem Cell Biol 2018;149(06):547-568
48 Nakagawa H. Analytical aspects: analysis of protein-bound glycans. In: Gabius H-J, ed. The Sugar Code. Fundamentals of Glycosciences. Weinheim, Germany: Wiley-VCH; 2009:71-83

49 Novotny MV, Alley WR Jr, Mann BF. Analytical glycobiology at high sensitivity: current approaches and directions. Glycoconj J 2013;30(02):89-117

50 Gabius H-J. How to crack the sugar code. Folia Biol (Praha) 2017; 63(04):121-131

51 Oscarson S. The chemist's way to synthesize glycosides. In: Gabius H-J, ed. The Sugar Code. Fundamentals of Glycosciences. Weinheim, Germany: Wiley-VCH; 2009:31-51

52 von der Lieth CW, Siebert HC, Kožár T, et al. Lectin ligands: new insights into their conformations and their dynamic behavior and the discovery of conformer selection by lectins. Acta Anat (Basel) 1998;161(1-4):91-109

53 Tyler A. An auto-antibody concept of cell structure, growth and differentiation. Growth 1946;10(06):7-19

54 Weiss P. The problem of specificity in growth and development. Yale J Biol Med 1947;19(03):235-278

55 Fischer E. Einfluss der Configuration auf die Wirkung der Enzyme. Ber Dtsch Chem Ges 1894;27:2985-2993

56 Mitchell SW. Researches upon the venom of the rattlesnake: with an investigation of the anatomy and physiology of the organs concerned. Smithsonian Contributions to Knowledge; 1860:89-90

57 Flexner S, Noguchi H. Snake venom in relation to haemolysis, bacteriolysis and toxicity. J Exp Med 1902;6(03):277-301

58 Gartner TK, Stocker K, Williams DC. Thrombolectin: a lectin isolated from Bothrops atrox venom. FEBS Lett 1980;117(01):13-16

59 Kocourek J. Historical background. In: Liener IE, Sharon N, Goldstein IJ, eds. The Lectins. Properties, Functions and Applications in Biology and Medicine. New York: Academic Press; 1986: $1-32$

60 Kilpatrick DC, Green C. Lectins as blood typing reagents. Adv Lectin Res 1992;5:51-94

61 Gabius H-J. The history of lectinology. In: Gabius H-J, ed. The Sugar Code. Fundamentals of Glycosciences. Weinheim, Germany: Wiley-VCH; 2009:261-268

62 Landsteiner K. Zur Kenntnis der antifermentativen, lytischen und agglutinierenden Wirkungen des Blutserums in der Lymphe. Zbl Bakteriol Orig 1900;27:357-362

63 Landsteiner K. Ueber Agglutinationserscheinungen normalen menschlichen Blutes. Wien Klin Wochenschr 1901;46:1132-1134

64 Boyd WC. The proteins of immune reactions. In: Neurath $\mathrm{H}$, Bailey K, eds. The Proteins. New York: Academic Press; 1954: 756-844

65 Boyd WC. The lectins: their present status. Vox Sang 1963; $8: 1-32$

66 Bird GWG. Lectins in immunohematology. Transfus Med Rev 1989;3(01):55-62

67 Nowell PC. Phytohemagglutinin: an initiator of mitosis in cultures of normal human leukocytes. Cancer Res 1960;20:462-466

68 Landsteiner $K$, Raubitschek $H$. Ueber die Adsorption von Immunstoffen. V. Mitteilung. Biochem Z 1909;15:33-51

69 Freier T, Fleischmann G, Rüdiger H. Affinity chromatography on immobilized hog gastric mucin and ovomucoid. A general method for isolation of lectins. Biol Chem Hoppe Seyler 1985; 366(11):1023-1028

70 Watkins WM, Morgan WTJ. Neutralization of the anti-H agglutinin in eel serum by simple sugars. Nature 1952;169 (4307):825-826

71 Watkins WM. A half century of blood-group antigen research: some personal recollections. Trends Glycosci Glycotechnol 1999; 11(62):391-411

72 Barondes SH. Bifunctional properties of lectins: lectins redefined. Trends Biochem Sci 1988;13(12):480-482

73 Gabius H-J, André S, Jiménez-Barbero J, Romero A, Solís D. From lectin structure to functional glycomics: principles of the sugar code. Trends Biochem Sci 2011;36(06):298-313 
74 Fujimoto Z, Tateno H, Hirabayashi J. Lectin structures: classification based on the 3-D structures. Methods Mol Biol 2014; 1200:579-606

75 Solís D, Bovin NV, Davis AP, et al. A guide into glycosciences: how chemistry, biochemistry and biology cooperate to crack the sugar code. Biochim Biophys Acta 2015;1850(01):186-235

76 Gabius H-J, Springer WR, Barondes SH. Receptor for the cell binding site of discoidin I. Cell 1985;42(02):449-456

77 Gabius H-J. Animal lectins. Eur J Biochem 1997;243(03):543-576

78 Gready JN, Zelensky AN. Routes in lectin evolution: case study on the C-type lectin-like domains. In: Gabius H-J, ed. The Sugar Code. Fundamentals of Glycosciences. Weinheim, Germany: Wiley-VCH; 2009:329-346

79 Drickamer K, Taylor ME. Recent insights into structures and functions of C-type lectins in the immune system. Curr Opin Struct Biol 2015;34:26-34

80 Mayer S, Raulf MK, Lepenies B. C-type lectins: their network and roles in pathogen recognition and immunity. Histochem Cell Biol 2017;147(02):223-237

81 Angata T, Brinkman-Van der Linden E. I-type lectins. Biochim Biophys Acta 2002;1572(2-3):294-316

82 Macauley MS, Crocker PR, Paulson JC. Siglec-mediated regulation of immune cell function in disease. Nat Rev Immunol 2014;14 (10):653-666

83 Hirabayashi J, ed. Recent topics on galectins. Trends Glycosci Glycotechnol 1997;9:1-180

84 Cooper DNW. Galectinomics: finding themes in complexity. Biochim Biophys Acta 2002;1572(2-3):209-231

85 Kaltner H, Toegel S, García Caballero G, Manning JC, Ledeen RW, Gabius HJ. Galectins: their network and roles in immunity/ tumor growth control. Histochem Cell Biol 2017;147(02): 239-256

86 García Caballero G, Manning JC, Ludwig A-K, et al. Members of the galectin network with deviations from the canonical sequence signature. 1. Galectin-Related Inter-Fiber Protein (GRIFIN). Trends Glycosci Glycotechnol 2018;30(172):SE1-SE9

87 Leffler H. Galectin history, some stories, and some outstanding questions. Trends Glycosci Glycotechnol 2018;30(172): SE129-SE135

88 Kasai K-i. Galectins: quadruple-faced proteins. Trends Glycosci Glycotechnol 2018;30(172):SE221-SE223

89 Kaltner H, Raschta A-S, Manning JC, Gabius HJ. Copy-number variation of functional galectin genes: studying animal galectin7 (p53-induced gene 1 in man) and tandem-repeat-type galectins-4 and -9. Glycobiology 2013;23(10):1152-1163

90 Gabius H-J, Manning JC, Kopitz J, André S, Kaltner H. Sweet complementarity: the functional pairing of glycans with lectins. Cell Mol Life Sci 2016;73(10):1989-2016

91 Iborra S, Sancho D. Signalling versatility following self and nonself sensing by myeloid C-type lectin receptors. Immunobiology 2015;220(02):175-184

92 Drummond RA, Brown GD. Signalling C-type lectins in antimicrobial immunity. PLoS Pathog 2013;9(07):e1003417

93 Shiokawa M, Yamasaki S, Saijo S. C-type lectin receptors in antifungal immunity. Curr Opin Microbiol 2017;40:123-130

94 Gabius H-J, Brehler R, Schauer A, Cramer F. Localization of endogenous lectins in normal human breast, benign breast lesions and mammary carcinomas. Virchows Arch B Cell Pathol Incl Mol Pathol 1986;52(02):107-115[Cell Pathol]

95 Kaltner H, García Caballero G, Sinowatz F, et al. Galectin-related protein: an integral member of the network of chicken galectins: 2. From expression profiling to its immunocyto- and histochemical localization and application as tool for ligand detection. Biochim Biophys Acta 2016;1860(10):2298-2312

96 Manning JC, García Caballero G, Knospe C, Kaltner H, Gabius HJ. Network analysis of adhesion/growth-regulatory galectins and their binding sites in adult chicken retina and choroid. J Anat 2017;231(01):23-37
97 Zivicová V, Broz P, Fík Z, et al. Genome-wide expression profiling (with focus on the galectin network) in tumor, transition zone and normal tissue of head and neck cancer: marked differences between individual patients and the site of specimen origin. Anticancer Res 2017;37(05):2275-2288

98 Manning JC, García Caballero G, Knospe C, Kaltner H, Gabius HJ. Three-step monitoring of glycan and galectin profiles in the anterior segment of the adult chicken eye. Ann Anat 2018;217:66-81

99 Kopitz J, Xiao Q, Ludwig A-K, et al. Reaction of a programmable glycan presentation of glycodendrimersomes and cells with engineered human lectins to show the sugar functionality of the cell surface. Angew Chem Int Ed Engl 2017;56(46):14677-14681

100 Xiao Q, Ludwig AK, Romanò C, et al. Exploring functional pairing between surface glycoconjugates and human galectins using programmable glycodendrimersomes. Proc Natl Acad Sci U S A 2018;115(11):E2509-E2518

101 Kopitz J, von Reitzenstein C, André S, et al. Negative regulation of neuroblastoma cell growth by carbohydrate-dependent surface binding of galectin-1 and functional divergence from galectin-3. J Biol Chem 2001;276(38):35917-35923

102 Weinmann D, Schlangen K, André S, et al. Galectin-3 induces a pro-degradative/inflammatory gene signature in human chondrocytes, teaming up with galectin-1 in osteoarthritis pathogenesis. Sci Rep 2016;6:39112

103 Weinmann D, Kenn M, Schmidt S, et al. Galectin-8 induces functional disease markers in human osteoarthritis and cooperates with galectins-1 and -3. Cell Mol Life Sci 2018;75(22):4187-4205

104 Gabius H-J, Roth J. An introduction to the sugar code. Histochem Cell Biol 2017;147(02):111-117

105 Schweizer A, Fransen JA, Bächi T, Ginsel L, Hauri HP. Identification, by a monoclonal antibody, of a $53-\mathrm{kD}$ protein associated with a tubulo-vesicular compartment at the cis-side of the Golgi apparatus. J Cell Biol 1988;107(05):1643-1653

106 Appenzeller C, Andersson H, Kappeler F, Hauri HP. The lectin ERGIC-53 is a cargo transport receptor for glycoproteins. Nat Cell Biol 1999;1(06):330-334

107 Nichols WC, Seligsohn U, Zivelin A, et al. Mutations in the ERGolgi intermediate compartment protein ERGIC-53 cause combined deficiency of coagulation factors V and VIII. Cell 1998;93 (01):61-70

108 Zhang B, Cunningham MA, Nichols WC, et al. Bleeding due to disruption of a cargo-specific ER-to-Golgi transport complex. Nat Genet 2003;34(02):220-225

109 Kawasaki N, Ichikawa Y, Matsuo I, et al. The sugar-binding ability of ERGIC-53 is enhanced by its interaction with MCFD2. Blood 2008;111(04):1972-1979

110 Yoshida Y. F-box proteins that contain sugar-binding domains. Biosci Biotechnol Biochem 2007;71(11):2623-2631

111 Aebi M, Bernasconi R, Clerc S, Molinari M. N-glycan structures: recognition and processing in the ER. Trends Biochem Sci 2010; 35(02):74-82

112 Roth J, Zuber C. Quality control of glycoprotein folding and ERAD: the role of N-glycan handling, EDEM1 and OS-9. Histochem Cell Biol 2017;147(02):269-284

113 Springer T, Galfré G, Secher DS, Milstein C. Mac-1: a macrophage differentiation antigen identified by monoclonal antibody. Eur J Immunol 1979;9(04):301-306

114 Josefsson EC, Gebhard HH, Stossel TP, Hartwig JH, Hoffmeister KM. The macrophage $\alpha_{M} \beta_{2}$ integrin $\alpha_{M}$ lectin domain mediates the phagocytosis of chilled platelets. J Biol Chem 2005;280(18): 18025-18032

115 Hoffmeister K, Falet H. Platelet glycoproteins as lectin in hematology. In: Gabius H-J, ed. The Sugar Code. Fundamentals of Glycosciences. Weinheim, Germany: Wiley-VCH; 2009:485-493

116 Yamanoi K, Nakayama J. Reduced $\alpha$ GlcNAc glycosylation on gastric gland mucin is a biomarker of malignant potential for gastric cancer, Barrett's adenocarcinoma, and pancreatic cancer. Histochem Cell Biol 2018;149(06):569-575 
117 Holla A, Skerra A. Comparative analysis reveals selective recognition of glycans by the dendritic cell receptors DC-SIGN and Langerin. Protein Eng Des Sel 2011;24(09):659-669

118 Feinberg H, Rowntree TJ, Tan SL, Drickamer K, Weis WI, Taylor ME. Common polymorphisms in human langerin change specificity for glycan ligands. J Biol Chem 2013;288(52):36762-36771

119 Pipirou Z, Powlesland AS, Steffen I, Pöhlmann S, Taylor ME, Drickamer K. Mouse LSECtin as a model for a human Ebola virus receptor. Glycobiology 2011;21(06):806-812

120 Davis CW, Mattei LM, Nguyen HY, Ansarah-Sobrinho C, Doms RW, Pierson TC. The location of asparagine-linked glycans on West Nile virions controls their interactions with CD209 (dendritic cell-specific ICAM-3 grabbing nonintegrin). J Biol Chem 2006;281(48):37183-37194

121 Powlesland AS, Ward EM, Sadhu SK, Guo Y, Taylor ME, Drickamer K. Widely divergent biochemical properties of the complete set of mouse DC-SIGN-related proteins. J Biol Chem 2006;281(29): 20440-20449

122 Sodetz JM, Paulson JC, Pizzo SV, McKee PA. Carbohydrate on human factor VIII/von Willebrand factor. Impairment of function by removal of specific galactose residues. J Biol Chem 1978;253 (20):7202-7206

123 Smedsrød B, Einarsson M, Pertoft H. Tissue plasminogen activator is endocytosed by mannose and galactose receptors of rat liver cells. Thromb Haemost 1988;59(03):480-484

124 Grozovsky R, Begonja AJ, Liu K, et al. The Ashwell-Morell receptor regulates hepatic thrombopoietin production via JAK2-STAT3 signaling. Nat Med 2015;21(01):47-54

125 Grewal PK, Uchiyama S, Ditto D, et al. The Ashwell receptor mitigates the lethal coagulopathy of sepsis. Nat Med 2008;14 (06):648-655

126 Ellies LG, Ditto D, Levy GG, et al. Sialyltransferase ST3Gal-IV operates as a dominant modifier of hemostasis by concealing asialoglycoprotein receptor ligands. Proc Natl Acad Sci U S A 2002;99(15):10042-10047

127 Unverzagt C, André S, Seifert J, et al. Structure-activity profiles of complex biantennary glycans with core fucosylation and with/ without additional $\alpha 2,3 / \alpha 2,6$ sialylation: synthesis of neoglycoproteins and their properties in lectin assays, cell binding, and organ uptake. J Med Chem 2002;45(02):478-491

128 Park EI, Mi Y, Unverzagt C, Gabius HJ, Baenziger JU. The asialoglycoprotein receptor clears glycoconjugates terminating with sialic acid $\alpha$ 2,6GalNAc. Proc Natl Acad Sci U S A 2005;102(47):17125-17129

129 Steirer LM, Park EI, Townsend RR, Baenziger JU. The asialoglycoprotein receptor regulates levels of plasma glycoproteins terminating with sialic acid $\alpha 2,6$-galactose. J Biol Chem 2009; 284(06):3777-3783

130 Iwaki J, Hirabayashi J. Carbohydrate-binding specificity of human galectins: an overview by frontal affinity chromatography. Trends Glycosci Glycotechnol 2018;30(172):SE137-SE153

131 Romaniuk MA, Tribulatti MV, Cattaneo V, et al. Human platelets express and are activated by galectin-8. Biochem J 2010;432(03): 535-547

132 Zappelli C, van der Zwaan C, Thijssen-Timmer DC, Mertens K, Meijer AB. Novel role for galectin-8 protein as mediator of coagulation factor $\mathrm{V}$ endocytosis by megakaryocytes. J Biol Chem 2012;287(11):8327-8335

133 Kamitori S. Three-dimensional structures of galectins. Trends Glycosci Glycotechnol 2018;30(172):SE41-SE50

134 Pegon JN, Kurdi M, Casari C, et al. Factor VIII and von Willebrand factor are ligands for the carbohydrate-receptor Siglec-5. Haematologica 2012;97(12):1855-1863

135 Krzeminski M, Singh T, André S, et al. Human galectin-3 (Mac-2 antigen): defining molecular switches of affinity to natural glycoproteins, structural and dynamic aspects of glycan binding by flexible ligand docking and putative regulatory sequences in the proximal promoter region. Biochim Biophys Acta 2011;1810(02): $150-161$
136 Nonaka M, Ma BY, Murai R, et al. Glycosylation-dependent interactions of C-type lectin DC-SIGN with colorectal tumorassociated Lewis glycans impair the function and differentiation of monocyte-derived dendritic cells. J Immunol 2008;180(05): 3347-3356

137 McEver RP. Selectins: novel receptors that mediate leukocyte adhesion during inflammation. Thromb Haemost 1991;65(03):223-228

138 Furie B, Furie BC, Flaumenhaft R. A journey with platelet Pselectin: the molecular basis of granule secretion, signalling and cell adhesion. Thromb Haemost 2001;86(01):214-221

139 Wu KK. TM hidden treasure: lectin-like domain. Blood 2012;119 (05):1103-1104

140 Gallatin WM, Weissman IL, Butcher EC. A cell-surface molecule involved in organ-specific homing of lymphocytes. Nature 1983; 304(5921):30-34

141 Bevilacqua MP, Pober JS, Mendrick DL, Cotran RS, Gimbrone MA Jr. Identification of an inducible endothelial-leukocyte adhesion molecule. Proc Natl Acad Sci U S A 1987;84(24):9238-9242

142 McEver RP, Martin MN. A monoclonal antibody to a membrane glycoprotein binds only to activated platelets. J Biol Chem 1984; 259(15):9799-9804

143 Stenberg PE, McEver RP, Shuman MA, Jacques YV, Bainton DF. A platelet $\alpha$-granule membrane protein (GMP-140) is expressed on the plasma membrane after activation. J Cell Biol 1985;101 (03):880-886

144 Berman CL, Yeo EL, Wencel-Drake JD, Furie BC, Ginsberg MH, Furie B. A platelet $\alpha$ granule membrane protein that is associated with the plasma membrane after activation. Characterization and subcellular localization of platelet activation-dependent granuleexternal membrane protein. J Clin Invest 1986;78(01):130-137

145 McEver RP. GMP-140: a receptor for neutrophils and monocytes on activated platelets and endothelium. J Cell Biochem 1991;45 (02):156-161

146 Geng JG, Bevilacqua MP, Moore KL, et al. Rapid neutrophil adhesion to activated endothelium mediated by GMP-140. Nature 1990;343(6260):757-760

147 Rosen SD, Singer MS, Yednock TA, Stoolman LM. Involvement of sialic acid on endothelial cells in organ-specific lymphocyte recirculation. Science 1985;228(4702):1005-1007

148 Ali S, Jenkins Y, Kirkley M, et al. Leukocyte extravasation: an immunoregulatory role for $\alpha$-L-fucosidase? J Immunol 2008;181 (04):2407-2413

149 Imai Y, Lasky LA, Rosen SD. Sulphation requirement for GlyCAM-1, an endothelial ligand for L-selectin. Nature 1993; 361(6412):555-557

150 Hooper LV, Manzella SM, Baenziger JU. The biology of sulfated oligosaccharides. In: Gabius H-J, Gabius S, eds. Glycosciences: Status and Perspectives. London, UK and Weinheim, Germany: Chapman \& Hall; 1997:261-276

151 Hemmerich S, Rosen SD. Carbohydrate sulfotransferases in lymphocyte homing. Glycobiology 2000;10(09):849-856

152 Fukuda M, Hiraoka N, Akama TO, Fukuda MN. Carbohydratemodifying sulfotransferases: structure, function, and pathophysiology. J Biol Chem 2001;276(51):47747-47750

153 Kawashima H. Two roles of mucin sulfation. Trends Glycosci Glycotechnol 2010;22(127):211-225

154 Baenziger JU. Glycoprotein hormone GalNAc-4-sulphotransferase. Biochem Soc Trans 2003;31(02):326-330

155 André S, Sanchez-Ruderisch H, Nakagawa H, et al. Tumor suppressor p16 $6^{\mathrm{INK} 4 \mathrm{a}}$-modulator of glycomic profile and galectin-1 expression to increase susceptibility to carbohydrate-dependent induction of anoikis in pancreatic carcinoma cells. FEBS J 2007; 274(13):3233-3256

156 Amano M, Eriksson H, Manning JC, et al. Tumour suppressor p16 $6^{\text {INK4a }}$ - anoikis-favouring decrease in N/O-glycan/cell surface sialylation by down-regulation of enzymes in sialic acid biosynthesis in tandem in a pancreatic carcinoma model. FEBS J 2012;279 (21):4062-4080 
157 Amano M, Galvan M, He J, Baum LG. The ST6Gal I sialyltransferase selectively modifies $\mathrm{N}$-glycans on CD45 to negatively regulate galectin-1-induced CD45 clustering, phosphatase modulation, and $\mathrm{T}$ cell death. J Biol Chem 2003;278(09): 7469-7475

158 Sperandio M. Selectins and glycosyltransferases in leukocyte rolling in vivo. FEBS J 2006;273(19):4377-4389

159 Marathe DD, Chandrasekaran EV, Lau JT, Matta KL, Neelamegham S. Systems-level studies of glycosyltransferase gene expression and enzyme activity that are associated with the selectin binding function of human leukocytes. FASEB J 2008;22(12): 4154-4167

160 Lo CY, Antonopoulos A, Gupta R, et al. Competition between core 2 GlcNAc-transferase and ST6GalNAc-transferase regulates the synthesis of the leukocyte selectin ligand on human P-selectin glycoprotein ligand-1. J Biol Chem 2013;288(20):13974-13987

161 Moreau R, Dausset J, Bernard J, Moullec J. Acquired hemolytic anemia with polyagglutinability of erythrocytes by a new factor present in normal blood [in French]. Bull Mem Soc Med Hop Paris 1957;73(20-21):569-587

162 Berger EG. Tn-syndrome. Biochim Biophys Acta 1999;1455(23):255-268

163 Ju T, Otto VI, Cummings RD. The Tn antigen-structural simplicity and biological complexity. Angew Chem Int Ed Engl 2011;50 (08):1770-1791

164 Hounsell EF, Davies MJ, Renouf DV. O-linked protein glycosylation structure and function. Glycoconj J 1996;13(01):19-26

165 Dam TK, Gerken TA, Brewer CF. Thermodynamics of multivalent carbohydrate-lectin cross-linking interactions: importance of entropy in the bind and jump mechanism. Biochemistry 2009; 48(18):3822-3827

166 Dam TK, Brewer CF. Multivalent lectin-carbohydrate interactions energetics and mechanisms of binding. Adv Carbohydr Chem Biochem 2010;63:139-164

167 Corfield AP. Mucins: a biologically relevant glycan barrier in mucosal protection. Biochim Biophys Acta 2015;1850(01): 236-252

168 Hurtado-Guerrero R. Recent structural and mechanistic insights into protein O-GalNAc glycosylation. Biochem Soc Trans 2016;44 (01):61-67

169 Tenno M, Ohtsubo K, Hagen FK, et al. Initiation of protein O glycosylation by the polypeptide GalNAcT-1 in vascular biology and humoral immunity. Mol Cell Biol 2007;27(24):8783-8796

170 Iida S, Yamamoto K, Irimura T. Interaction of human macrophage C-type lectin with $\mathrm{O}$-linked $\mathrm{N}$-acetylgalactosamine residues on mucin glycopeptides. J Biol Chem 1999;274(16): 10697-10705

$171 \mathrm{Wu}$ AM, Wu JH, Liu J-H, et al. Effects of polyvalency of glycotopes and natural modifications of human blood group $\mathrm{ABH} /$ Lewis sugars at the Gal $\beta 1$-terminated core saccharides on the binding of domain-I of recombinant tandem-repeat-type galectin-4 from rat gastrointestinal tract (G4-N). Biochimie 2004;86 (4-5):317-326

172 Wahrenbrock MG, Varki A. Multiple hepatic receptors cooperate to eliminate secretory mucins aberrantly entering the bloodstream: are circulating cancer mucins the "tip of the iceberg"? Cancer Res 2006;66(04):2433-2441

173 Li Y, Fu J, Ling Y, et al. Sialylation on O-glycans protects platelets from clearance by liver Kupffer cells. Proc Natl Acad Sci U S A 2017;114(31):8360-8365

174 Mortezai N, Behnken HN, Kurze AK, et al. Tumor-associated Neu5Ac-Tn and Neu5Gc-Tn antigens bind to C-type lectin CLEC10A (CD301, MGL). Glycobiology 2013;23(07):844-852

175 Takamiya R, Ohtsubo K, Takamatsu S, Taniguchi N, Angata T. The interaction between Siglec-15 and tumor-associated sialyl-Tn antigen enhances TGF- $\beta$ secretion from monocytes/macrophages through the DAP12-Syk pathway. Glycobiology 2013; 23(02):178-187
176 Angata T, Tabuchi Y, Nakamura K, Nakamura M. Siglec-15: an immune system Siglec conserved throughout vertebrate evolution. Glycobiology 2007;17(08):838-846

177 Lu Q Lu G, Qi J, et al. PILR $\alpha$ and PILR $\beta$ have a siglec fold and provide the basis of binding to sialic acid. Proc Natl Acad Sci U S A 2014;111(22):8221-8226

178 Kuroki K, Wang J, Ose T, et al. Structural basis for simultaneous recognition of an $\mathrm{O}$-glycan and its attached peptide of mucin family by immune receptor PILR $\alpha$. Proc Natl Acad Sci U S A 2014; 111(24):8877-8882

179 Gabius H-J, Kaltner H, Kopitz J, André S. The glycobiology of the CD system: a dictionary for translating marker designations into glycan/lectin structure and function. Trends Biochem Sci 2015; 40(07):360-376

180 Rodriguez MC, Yegorova S, Pitteloud JP, et al. Thermodynamic switch in binding of adhesion/growth regulatory human galectin-3 to tumor-associated TF antigen (CD176) and MUC1 glycopeptides. Biochemistry 2015;54(29):4462-4474

181 Artigas G, Hinou H, Garcia-Martin F, Gabius HJ, Nishimura SI. Synthetic mucin-like glycopeptides as versatile tools to measure effects of glycan structure/density/position on the interaction with adhesion/growth-regulatory galectins in arrays. Chem Asian J 2017;12(01):159-167

182 Crocker PR, Hartnell A, Munday J, Nath D. The potential role of sialoadhesin as a macrophage recognition molecule in health and disease. Glycoconj J 1997;14(05):601-609

183 Beatson R, Tajadura-Ortega V, Achkova D, et al. The mucin MUC1 modulates the tumor immunological microenvironment through engagement of the lectin Siglec-9. Nat Immunol 2016; 17(11):1273-1281

184 Blixt O, Collins BE, van den Nieuwenhof IM, Crocker PR, Paulson JC. Sialoside specificity of the siglec family assessed using novel multivalent probes: identification of potent inhibitors of myelin-associated glycoprotein. J Biol Chem 2003;278(33): 31007-31019

185 Bannert N, Craig S, Farzan M, et al. Sialylated O-glycans and sulfated tyrosines in the $\mathrm{NH} 2$-terminal domain of CC chemokine receptor 5 contribute to high affinity binding of chemokines. J Exp Med 2001;194(11):1661-1673

186 Frommhold D, Ludwig A, Bixel MG, et al. Sialyltransferase ST3Gal-IV controls CXCR2-mediated firm leukocyte arrest during inflammation. J Exp Med 2008;205(06):1435-1446

187 Sperandio $M$. The expanding role of $\alpha 2-3$ sialylation for leukocyte trafficking in vivo. Ann N Y Acad Sci 2012;1253:201-205

188 Kudelka MR, Ju T, Heimburg-Molinaro J, Cummings RD. Simple sugars to complex disease-mucin-type O-glycans in cancer. Adv Cancer Res 2015;126:53-135

189 Dimitroff CJ. Galectin-binding O-glycosylations as regulators of malignancy. Cancer Res 2015;75(16):3195-3202

190 Murugaesu N, Iravani M, van Weverwijk A, et al. An in vivo functional screen identifies ST6GalNAc2 sialyltransferase as a breast cancer metastasis suppressor. Cancer Discov 2014;4(03): 304-317

191 Reticker-Flynn NE, Bhatia SN. Aberrant glycosylation promotes lung cancer metastasis through adhesion to galectins in the metastatic niche. Cancer Discov 2015;5(02):168-181

192 Galvan M, Tsuboi S, Fukuda M, Baum LG. Expression of a specific glycosyltransferase enzyme regulates $\mathrm{T}$ cell death mediated by galectin-1. J Biol Chem 2000;275(22):16730-16737

193 Cabrera PV, Amano M, Mitoma J, et al. Haploinsufficiency of C2GnT-I glycosyltransferase renders T lymphoma cells resistant to cell death. Blood 2006;108(07):2399-2406

194 Valenzuela HF, Pace KE, Cabrera PV, et al. O-glycosylation regulates LNCaP prostate cancer cell susceptibility to apoptosis induced by galectin-1. Cancer Res 2007;67(13):6155-6162

195 Tsuboi S, Sutoh M, Hatakeyama S, et al. A novel strategy for evasion of NK cell immunity by tumours expressing core 2 O-glycans. EMBO J 2011;30(15):3173-3185 
196 Ledeen RW, Kopitz J, Abad-Rodríguez J, Gabius HJ. Glycan chains of gangliosides: functional ligands for tissue lectins (siglecs/ galectins). Prog Mol Biol Transl Sci 2018;156:289-324

197 Bucior I, Burger MM. Fernàndez-Busquets. Carbohydrate-carbohydrate interactions. In: Gabius H-J, ed. The Sugar Code. Fundamentals of Glycosciences. Weinheim, Germany: WileyVCH; 2009:347-362

198 Sanchez-Ruderisch H, Fischer C, Detjen KM, et al. Tumor suppressor $\mathrm{p} 16^{\mathrm{INK} 4 a}$ : downregulation of galectin-3, an endogenous competitor of the pro-anoikis effector galectin-1, in a pancreatic carcinoma model. FEBS J 2010;277(17):3552-3563

199 Ruiz FM, Gilles U, Ludwig A-K, et al. Chicken GRIFIN: structural characterization in crystals and in solution. Biochimie 2018; 146:127-138

200 Kopitz J, Vértesy S, André S, Fiedler S, Schnölzer M, Gabius HJ. Human chimera-type galectin-3: defining the critical tail length for high-affinity glycoprotein/cell surface binding and functional competition with galectin-1 in neuroblastoma cell growth regulation. Biochimie 2014;104:90-99

201 Flores-Ibarra A, Vértesy S, Medrano FJ, Gabius HJ, Romero A. Crystallization of a human galectin-3 variant with two ordered segments in the shortened N-terminal tail. Sci Rep 2018;8(01): 9835

202 Springer TA. Monoclonal antibody analysis of complex biological systems. Combination of cell hybridization and immunoadsorbents in a novel cascade procedure and its application to the macrophage cell surface. J Biol Chem 1981;256(08): 3833-3839

203 Ho MK, Springer TA. Mac-2, a novel 32,000 Mr mouse macrophage subpopulation-specific antigen defined by monoclonal antibodies. J Immunol 1982;128(03):1221-1228

204 Flotte TJ, Springer TA, Thorbecke GJ. Dendritic cell and macrophage staining by monoclonal antibodies in tissue sections and epidermal sheets. Am J Pathol 1983;111(01):112-124

205 Hughes RC. Mac-2: a versatile galactose-binding protein of mammalian tissues. Glycobiology 1994;4(01):5-12

206 Dawson H, André S, Karamitopoulou E, Zlobec I, Gabius HJ. The growing galectin network in colon cancer and clinical relevance of cytoplasmic galectin-3 reactivity. Anticancer Res 2013;33 (08):3053-3059

207 Ahmad N, Gabius H-J, André S, et al. Galectin-3 precipitates as a pentamer with synthetic multivalent carbohydrates and forms heterogeneous cross-linked complexes. J Biol Chem 2004;279 (12):10841-10847

208 Halimi H, Rigato A, Byrne D, et al. Glycan dependence of Galectin3 self-association properties. PLoS One 2014;9(11):e111836

209 Ippel H, Miller MC, Vértesy S, et al. Intra- and intermolecular interactions of human galectin-3: assessment by full-assignment-based NMR. Glycobiology 2016;26(08):888-903

210 Lin YH, Qiu DC, Chang WH, et al. The intrinsically disordered Nterminal domain of galectin-3 dynamically mediates multisite self-association of the protein through fuzzy interactions. J Biol Chem 2017;292(43):17845-17856

211 Linsley PS, Horn D, Marquardt H, et al. Identification of a novel serum protein secreted by lung carcinoma cells. Biochemistry 1986;25(10):2978-2986

212 Rosenberg I, Cherayil BJ, Isselbacher KJ, Pillai S. Mac-2-binding glycoproteins. Putative ligands for a cytosolic $\beta$-galactoside lectin. J Biol Chem 1991;266(28):18731-18736
213 Sasaki T, Brakebusch C, Engel J, Timpl R. Mac-2 binding protein is a cell-adhesive protein of the extracellular matrix which selfassembles into ring-like structures and binds $\beta 1$ integrins, collagens and fibronectin. EMBO J 1998;17(06):1606-1613

214 DeRoo EP, Wrobleski SK, Shea EM, et al. The role of galectin-3 and galectin-3-binding protein in venous thrombosis. Blood 2015; 125(11):1813-1821

215 Blostein M, Cuerquis J, Galipeau J. Galectin 3-binding protein is a potential contaminant of recombinantly produced factor IX. Haemophilia 2007;13(06):701-706

216 Papaspyridonos M, McNeill E, de Bono JP, et al. Galectin-3 is an amplifier of inflammation in atherosclerotic plaque progression through macrophage activation and monocyte chemoattraction. Arterioscler Thromb Vasc Biol 2008;28(03):433-440

217 Filer A, Bik M, Parsonage GN, et al. Galectin 3 induces a distinctive pattern of cytokine and chemokine production in rheumatoid synovial fibroblasts via selective signaling pathways. Arthritis Rheum 2009;60(06):1604-1614

218 Miller MC, Ludwig A-K, Wichapong K, et al. Adhesion/growthregulatory galectins tested in combination: evidence for formation of hybrids as heterodimers. Biochem J 2018;475(05): 1003-1018

219 Vértesy S, Michalak M, Miller MC, et al. Structural significance of galectin design: impairment of homodimer stability by linker insertion and partial reversion by ligand presence. Protein Eng Des Sel 2015;28(07):199-210

220 Sharon N. Glycoproteins now and then: a personal account. Acta Anat (Basel) 1998;161(1-4):7-17

221 Damjanov I. Lectin cytochemistry and histochemistry. Lab Invest 1987;57(01):5-20

222 Spicer SS, Schulte BA. Detection and differentiation of glycoconjugates in various cell types by lectin histochemistry. Basic Appl Histochem 1988;32(03):307-320

223 Gabius H-J, Wosgien B, Hendrys M, Bardosi A. Lectin localization in human nerve by biochemically defined lectin-binding glycoproteins, neoglycoprotein and lectin-specific antibody. Histochemistry 1991;95(03):269-277

224 Spicer SS, Schulte BA. Diversity of cell glycoconjugates shown histochemically: a perspective. J Histochem Cytochem 1992;40 (01):1-38

225 Danguy A, Akif F, Pajak B, Gabius HJ. Contribution of carbohydrate histochemistry to glycobiology. Histol Histopathol 1994;9 (01):155-171

226 Roth J. Lectins for histochemical demonstration of glycans. Histochem Cell Biol 2011;136(02):117-130

227 Roy R, Cao Y, Kaltner H, et al. Teaming up synthetic chemistry and histochemistry for activity screening in galectin-directed inhibitor design. Histochem Cell Biol 2017;147(02):285-301

228 Gabius H-J. Cell surface glycans: the why and how of their functionality as biochemical signals in lectin-mediated information transfer. Crit Rev Immunol 2006;26(01):43-79

229 Randi AM, Smith KE, Castaman G. von Willebrand factor regulation of blood vessel formation. Blood 2018;132(02):132-140

230 Degn SE, Jensenius JC, Bjerre M. The lectin pathway and its implications in coagulation, infections and auto-immunity. Curr Opin Organ Transplant 2011;16(01):21-27

231 Larsen JB, Hvas CL, Hvas AM. The lectin pathway in thrombotic conditions-a systematic review. Thromb Haemost 2018;118 (07):1141-1166 